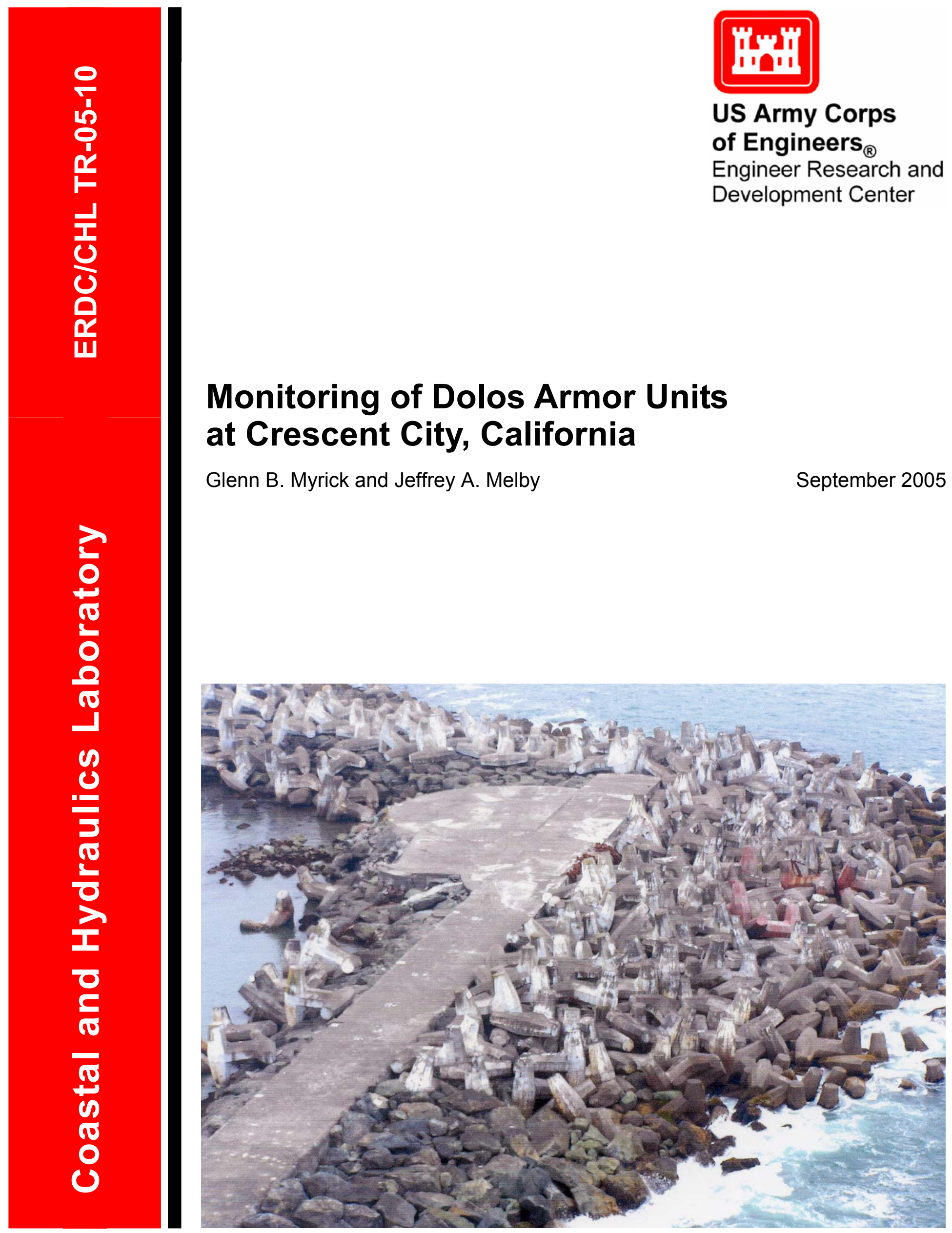




\section{Monitoring of Dolos Armor Units at Crescent City, California}

Glenn B. Myrick and Jeffrey A. Melby

Coastal and Hydraulics Laboratory

U.S. Army Engineer Research and Development Center

3909 Halls Ferry Road

Vicksburg, MS 39180-6199

Final report

Approved for public release; distribution is unlimited 


\begin{abstract}
Crescent City breakwater is located on the California coastline approximately 17 miles south of the Oregon border. In 1974 and again in 1986, dolosse were placed along a section of the breakwater particularly susceptible to damage. Monitoring of above water dolosse moment and breakage has been conducted since 1986. In August of 2004, a detailed monitoring survey was conducted of the dolos section of the Crescent City breakwater. The goal of this monitoring is to understand the long-term structural response of the dolosse. Detailed monitoring included ground surveys, aerial photography, photogrammetric analysis, and a broken armor unit survey. Results showed very little dolos movement has occurred since the end of the initial nesting period in 1988. Furthermore, no additional dolos breakage was observed since 1993. From 1995 to 1999, core samples were obtained from dolosse cast in 1986 and in 1974 in order to determine the in-situ strength of units in both non-loaded (near concrete cap) and highly loaded regions (near still water level) of the structure. The cores were subjected to standard laboratory concrete strength tests. Results indicated that the structural strength has increased considerably since construction for non-loaded units. However, concrete strength for units placed in highly loaded units near the still water level was near constant.
\end{abstract}

DISCLAIMER: The contents of this report are not to be used for advertising, publication, or promotional purposes. Citation of trade names does not constitute an official endorsement or approval of the use of such commercial products. All product names and trademarks cited are the property of their respective owners. The findings of this report are not to be construed as an official Department of the Army position unless so designated by other authorized documents. 


\section{Contents}

Conversion Factors, Non-SI to SI Units of Measurement....................................

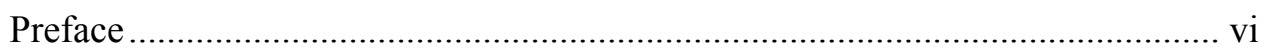

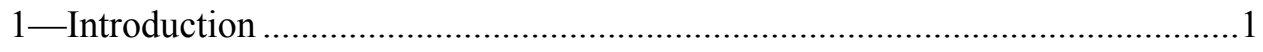

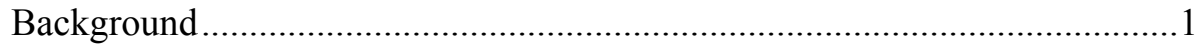

Project Location and Brief History ..............................................................

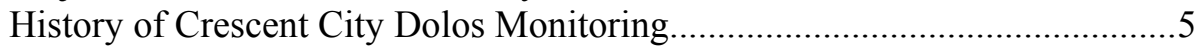

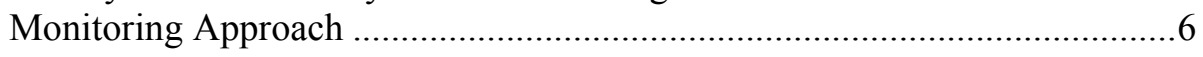

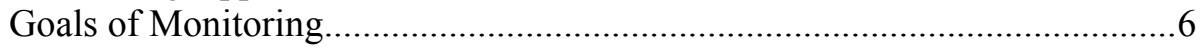

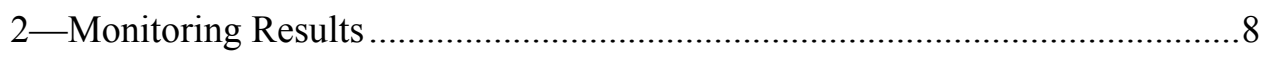

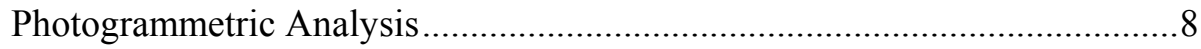

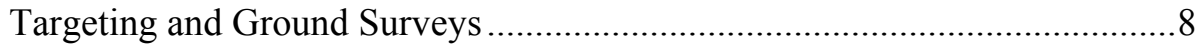

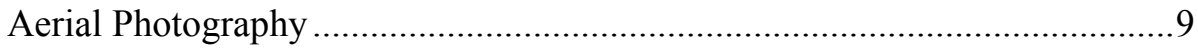

Photogrammetry Analysis Results .......................................................... 9

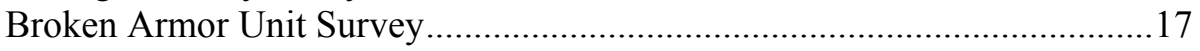

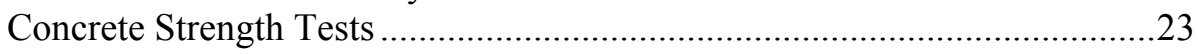

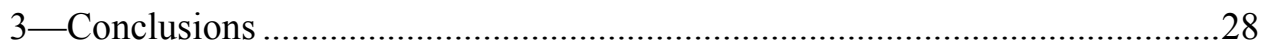

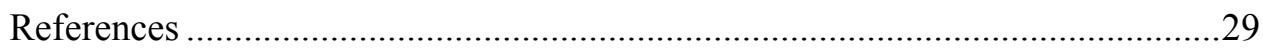

SF 298

\section{List of Figures}

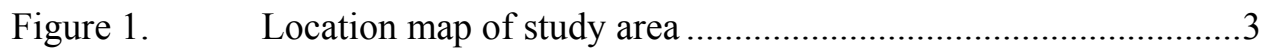

Figure 2. Aerial photograph of outer breakwater ...................................... 3

Figure 3. Cross section of Crescent City breakwater after 1986 rehabilitation.............................................................................. 4

Figure 4. 1986 repair section at elbow with red instrumented dolosse in test section near center of photograph....................... 4

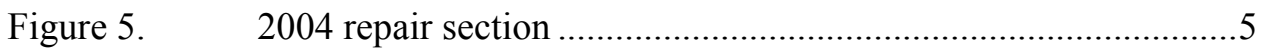


Figure 6. View of Crescent City breakwater elbow from center of breakwater cap looking south.....................................................5

Figure 7. Examples of targets from aerial (A) and ground (B)

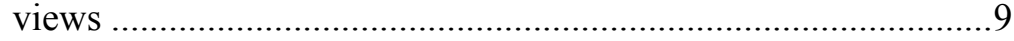

Figure 8. Location of dolosse with significant movement........................10

Figure 9. Details of cumulative movement of dolos A through 2004.

Figure 10. Details of cumulative movement of dolos F through 2004. 12

Figure 11. Details of cumulative movement of dolos G through 2004. 13

Figure 12. Details of cumulative movement of dolos $\mathrm{N}$ through 2004. 14

Figure 13. Details of cumulative movement of dolos 3 through 2004. 15

Figure 14. Details of cumulative movement of dolos 8 through 2004. .16

Figure 15. Example of a straight fluke-shank dolos break .........................18

Figure 16. Example of a shank-fluke dolos break ......................................18

Figure 17. Example of a mid-shank dolos break ........................................19

Figure 18. Overall aerial view of locations of broken/cracked dolosse...... .21

Figure 19. Locations of broken/cracked dolosse along the southerly

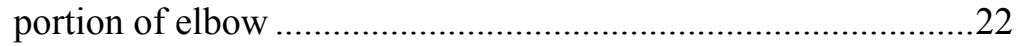

Figure 20. Locations of broken/cracked dolosse along the northerly

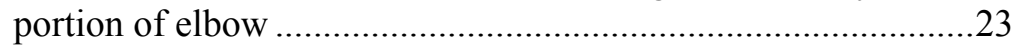

Figure 21. Location of cored dolosse ……............................................24

Figure 22. Compressive strength as a function of age ................................26

Figure 23. Flexural tensile strength as a function of age ............................26

\section{List of Tables}

Table 1. Significant Movements of Targeted Dolosse Relative to 1999 and Cumulative from 1986............................................17

Table 2. Broken Dolos Inventory Data ..................................................19

Table 3. Concrete Strength Test Results ...............................................27 


\section{Conversion Factors, Non-SI to SI Units of Measurement}

Non-SI units of measurements used in figures, plates, and tables of this report can be converted to SI units as follows:

\begin{tabular}{|l|l|l||}
\hline \hline Multiply & By & To Obtain \\
\hline \hline degrees (angle) & 0.01745329 & radians \\
\hline feet & 30.48 & centimeters \\
\hline feet & 0.3048 & meters \\
\hline inches & 0.0254 & meters \\
\hline inches & 2.54 & centimeters \\
\hline miles (U.S. statute) & 1.609347 & kilometers \\
\hline pounds (mass) & 0.4535924 & kilograms \\
\hline tons (2000 pounds, mass) & 907.1847 & kilograms \\
\hline \hline
\end{tabular}




\section{Preface}

This report describes procedures and results of monitoring dolos concrete armor units on the Crescent City, California, outer breakwater. The study was performed by the Coastal and Hydraulics Laboratory (CHL), U.S. Army Engineer Research and Development Center (ERDC), for Headquarters, U.S. Army Corps of Engineers (HQUSACE).

The study reported herein was conducted as part of the Monitoring Completed Navigation Projects (MCNP) Program under the "Periodic Inspections" work unit. HQUSACE administers the overall program. CHL manages the program. The principal investigator for the Periodic Inspections work unit is Dr. Jeffery A. Melby, CHL. The Program Manager for the MCNP Program is Dr. Lyndell Z. Hales, CHL. Technical Monitors for the MCNP Program are Messrs. Barry W. Holliday, Charles B. Chesnutt, and David B. Wingerd, HQUSACE. Ms. Lisa Romanoski, U. S. Army Engineer District, San Francisco was the point-of-contact for the study.

Richard B. Davis, Inc., Smith River, CA, provided ground surveys, aerial photography, and photogrammetric analysis under contract to the Portland District, U. S. Army Corps of Engineers. Dr. Melby and Messrs. Glenn B. Myrick and Larry R. Tolliver, CHL, conducted a walking survey of the structure. The surveys were performed during July and August 2004, and this report was prepared during the period October 2004 through June 2005. This study was performed under the general supervision of Mr. Thomas W. Richardson, Director, CHL. Direct supervision of this project was provided by Mr. Dennis G. Markle, Chief, Harbors, Entrances, and Structures Branch (HESB), and Mr. Jose Sanchez, Acting Chief, HESB.

At the time of publication of this report, Dr. James R. Houston was Director of ERDC, and COL James R. Rowan, EN, was Commander and Executive Director. 


\section{Introduction}

\section{Background}

The U. S. Army Corps of Engineers began a research program in 1978 known as the Monitoring of Completed Coastal Projects (MCCP). This program was expanded in the late 1990s to include inland navigation projects and renamed Monitoring Completed Navigation Projects (MCNP) Program (Hales and Richey 2004). One of the main objectives of the MCNP program is to monitor existing navigation structures in order to determine their structural and functional performance. The results can be used to improve design methods, construction practices, and cost effectiveness of the structures, aid in the calibration and verification of numerical models, and improve operations and maintenance techniques. The average length of continuous monitoring of specific projects in the MCNP program is 3 to 5 years.

The Periodic Inspections work unit was initiated in 1993 in order to provide long-term structural performance monitoring. Sites are selected from previous MCCP or MCNP projects or based on the site's unique design features. Each site selected for inclusion to the Periodic Inspections work unit has a relatively intensive baseline survey during the initial monitoring. The structures are then monitored periodically, based on prioritized needs and funding, and evaluated for structural changes. The dolos section of the Crescent City, California, breakwater was selected for inclusion to the Periodic Inspections work.

\section{Project Location and Brief History}

Crescent City harbor is located on the northern California coastline, approximately $27 \mathrm{~km}$ (17 miles) south of the Oregon border. Harbor location and layout can be seen in Figure 1. In 1920, construction began on a rubble mound structure that was to become the Crescent City outer breakwater. The purpose of the breakwater was to provide a quiescent harbor area for mooring commercial vessels, pleasure craft, and U.S. Coast Guard vessels as well as port operations supporting local supply, the fishing fleet, and the lumber industry.

The initial breakwater was constructed to a length of $684 \mathrm{~m}(2,245 \mathrm{ft})$ extending south from Battery Point, the northern seaward point of the natural Crescent City bay. The structure had a traditional trapezoidal section with 9,070$\mathrm{kg}$ (10-ton) armor stone up to an elevation of 1.8-3.4 m (6-11 ft) mean lower low 
water (mllw). This was completed in 1926. By 1931, $230 \mathrm{~m}$ (755 ft) had been

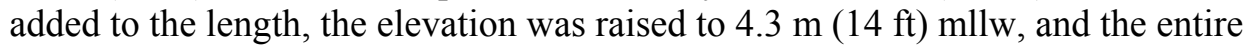
914-m (3,000-ft) long structure had been protected with a 4.3-m (14-ft) wide solid concrete cap. In 1948, the structure was extended $305 \mathrm{~m}(1,000 \mathrm{ft})$ with the intention to eventually extend out to Round Rock. Subsequent storms of 1948 and 1949 severely damaged portions of the breakwater extending beyond station $37+00(\mathrm{ft})$, requiring reconstruction and improvements on two occasions. Winter storms of 1950-51 resulted in the displacement of the concrete cap and armor stones down to approximately $0.0 \mathrm{mllw}$ beyond station $37+00$. Finally, in 1952, the existing structure south of station $36+70$ (ft) was abandoned and a dogleg extension added. The modification, a $0.3-\mathrm{km}(984-\mathrm{ft})$ long extension of the breakwater on a bearing of $\mathrm{S} 80^{\circ} \mathrm{E}$, was completed in 1957. The trunk section of the dogleg to station $41+20$ (ft) was constructed using $10,885 \mathrm{~kg}$ (12 ton) armor stone. Stations $41+20$ to $46+70$ were constructed using $1,83622,680-\mathrm{kg}$ (25-ton) unreinforced tetrapods on the seaward slope based on successful small-scale model two-dimensional stability tests (Hudson and Jackson 1955 and 1956). Tetrapods, 140 in count, were stockpiled along the first $61 \mathrm{~m}(200 \mathrm{ft})$ of the dogleg (stations $37+00$ to $39+00$ ) near the elbow. There were no threedimensional laboratory stability tests conducted to verify stability of the tetrapods near the elbow. Most of the tetrapods near the elbow were broken or displaced just after being set. The remainder of the tetrapods placed along the dogleg remained stable.

In 1974, two layers (246 units) of 36,290-kg (40-ton) unreinforced dolosse were placed on the seaward slope between stations $34+70$ and $37+00(\mathrm{ft})$. A survey of broken dolosse was conducted in August 1982 that showed approximately 70 of the original 246 dolosse were broken (Edminsten 1982), of which 22 were documented as broken during placement. Storms in the winter of 1983 caused severe damage and deterioration to the dolosse. Three-dimensional stability studies were conducted at the Waterways Experiment Station's (WES's) Coastal Engineering Research Center (CERC) in 1984 and 1985 to develop a technically sound repair plan. These studies quantified the number of 38,100-kg (42-ton) dolosse required, the optimum slope needed, overall constructability, and methods of stabilization of the transition areas (Baumgartner, Carver, and Davidson 1985). In 1986, 760 fiber-reinforced 38,100-kg (42-ton) dolosse were placed on the breakwater. Of those, 680 new dolosse, along with the remaining 1974

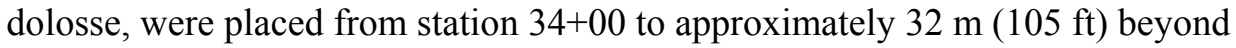
station $37+00$. The remainder of the units was stockpiled on the harbor side of the structure. The 1986 post-rehabilitation breakwater is shown in Figure 2. A typical cross section of the 1986 rehabilitation section near the elbow can be seen in Figure 3. Figure 4 shows an aerial view of the dolos section in 1986. Figure 5 shows the dolos section in 2004 for comparison. Figure 6 shows the dolos section and cap looking south in 2004. More historical details may be found in USAE District, San Francisco (1992), Bottin (1988), Kendall (1988), Kendall and Melby (1989 and 1992), and Markle and Greer (1992). 


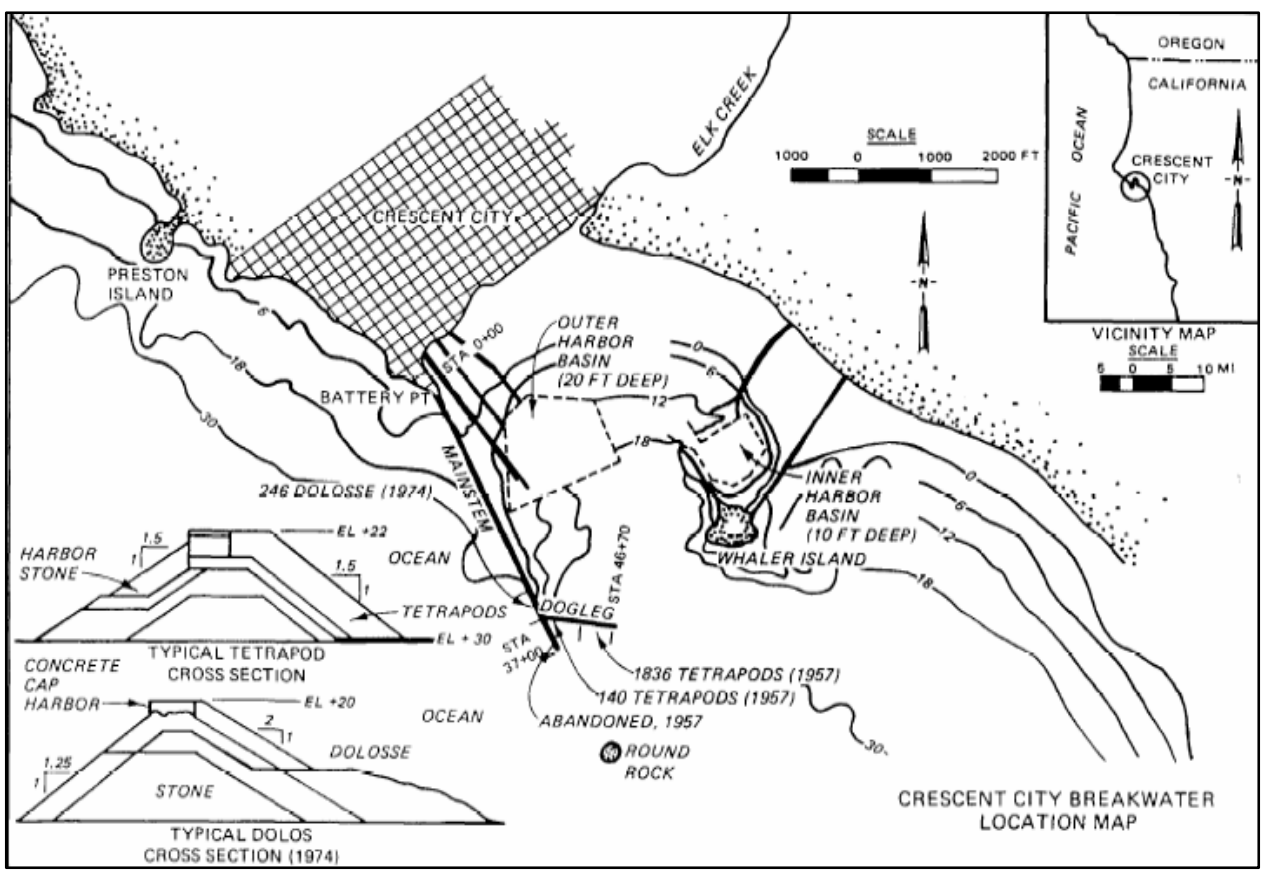

Figure 1. Location map of study area

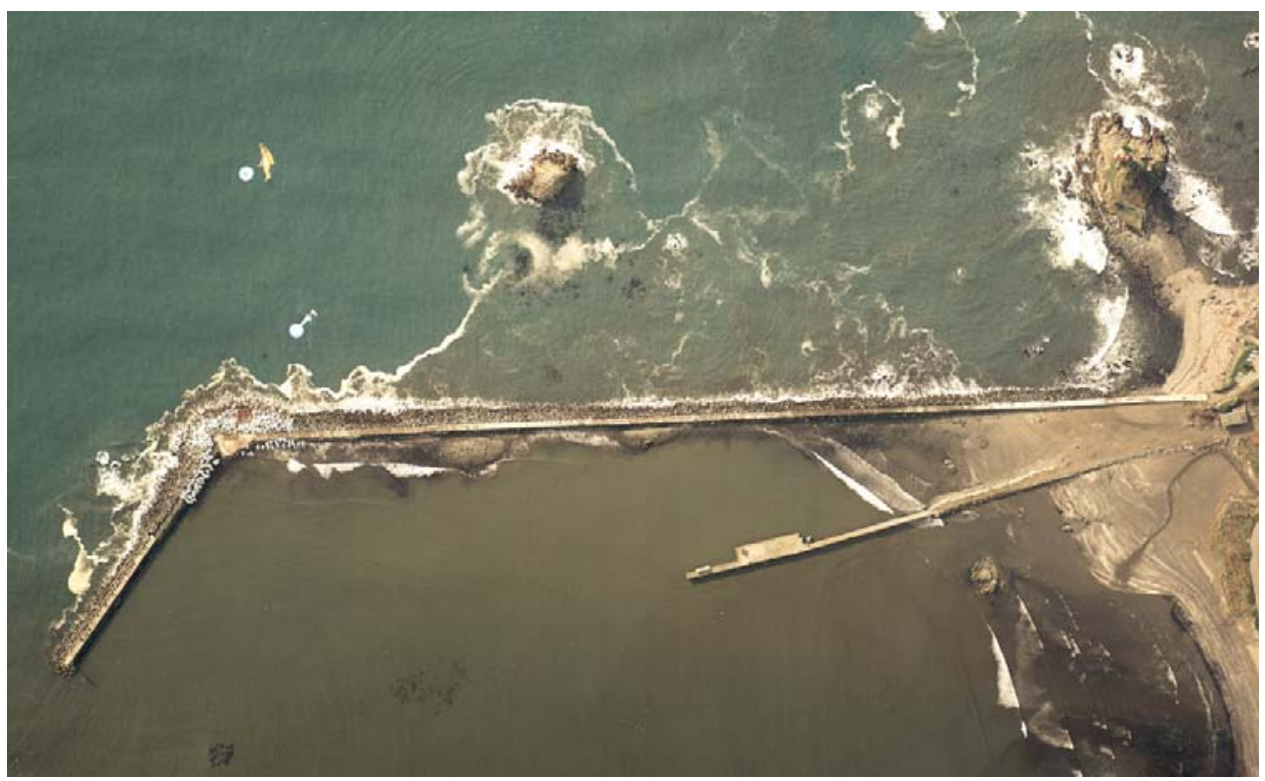

Figure 2. Aerial photograph of outer breakwater 


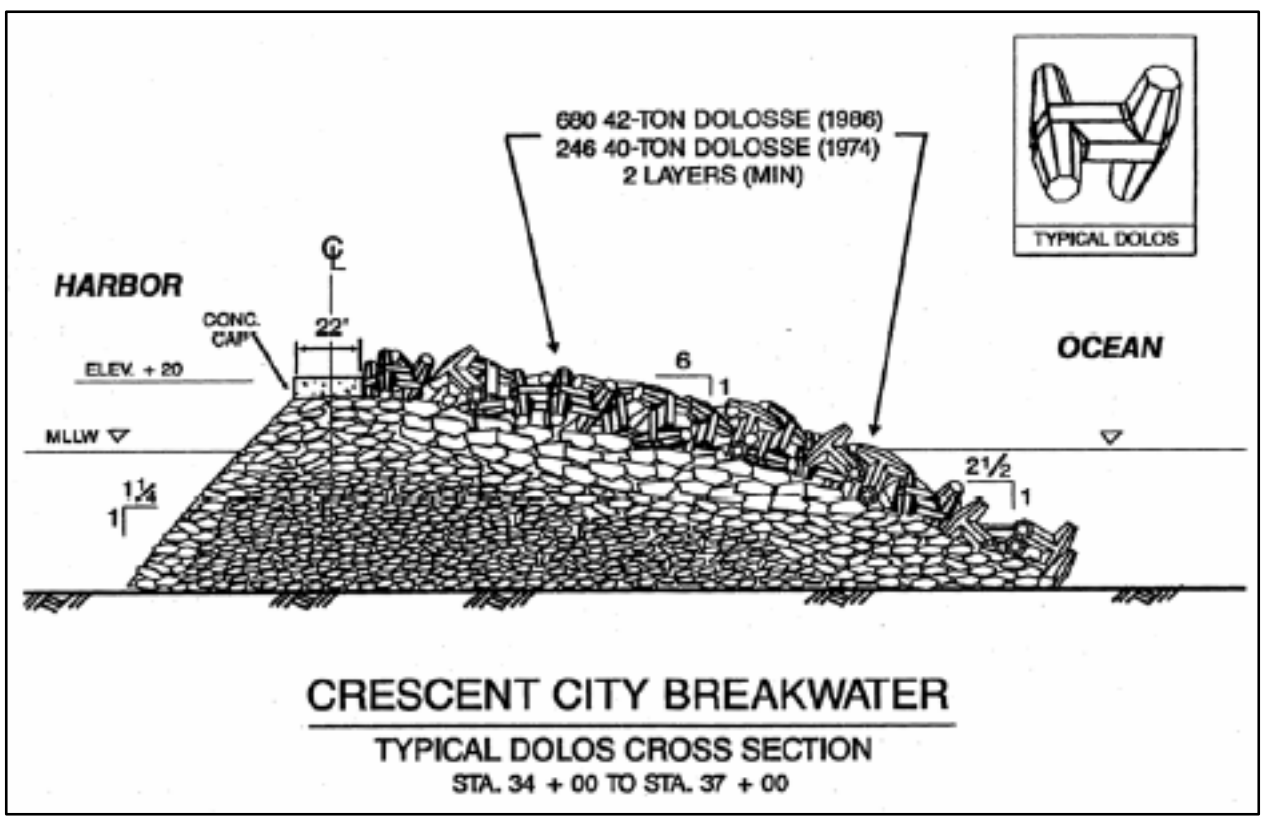

Figure 3. Cross section of Crescent City breakwater after 1986 rehabilitation

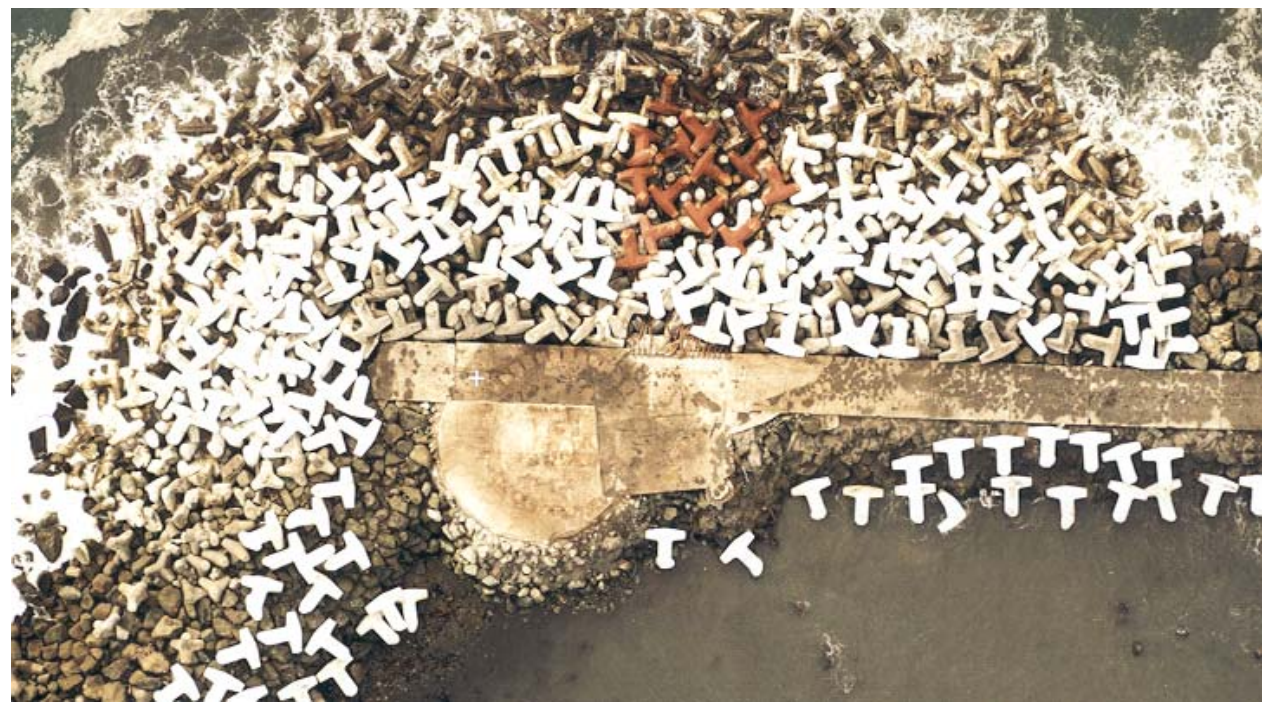

Figure 4. 1986 repair section at elbow with red instrumented dolosse in test section near center of photograph 


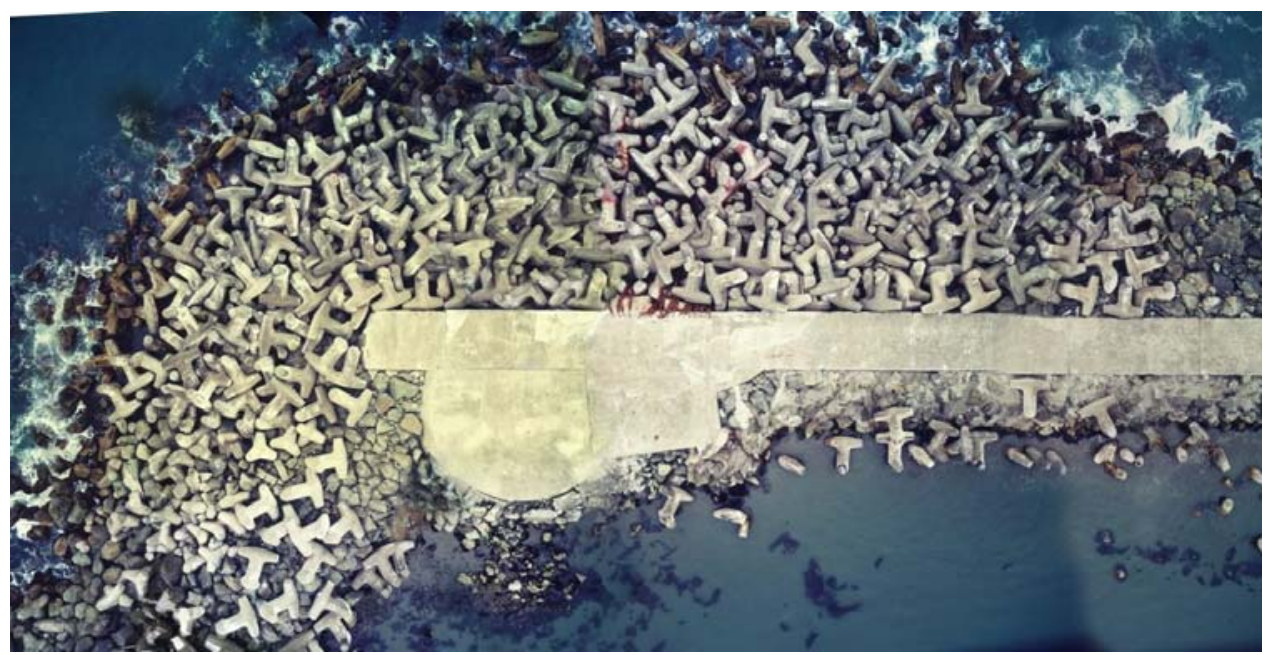

Figure 5. 2004 repair section

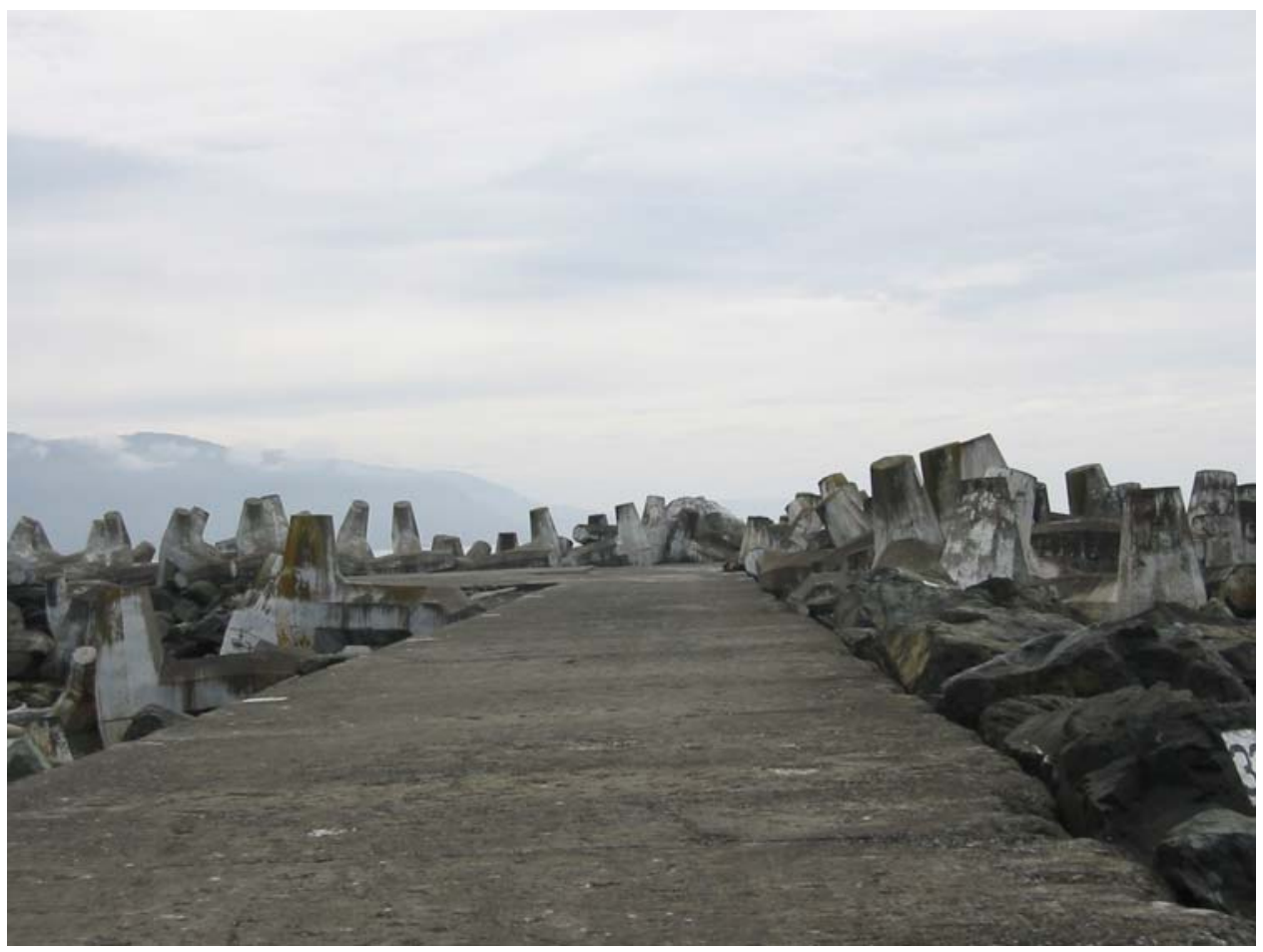

Figure 6. View of Crescent City breakwater elbow from center of breakwater cap looking south

\section{History of Crescent City Dolos Monitoring}

An extensive monitoring effort has been conducted on the Crescent City breakwater since the 1986 rehabilitation. The monitoring effort began during the 1986 rehabilitation. Twenty of the 680 dolosse were instrumented with internal strain gages and 6 had accelerometers in order to measure structural response to static and wave-induced loads. Baumgartner et al. (1985), Howell (1985 and 
1986), and Kendall et al. (1985) reported on the design of the early monitoring effort. The focus at the time was dolos structural monitoring, but Kendall (1988) also discussed photogrammetric monitoring of the dolos movements. Kendall (1988), Rosati and Howell (1988, 1990), Howell and Melby (1991), Kendall and Melby $(1989,1992)$, Markle and Greer (1992), and USAE District, San Francisco (1992) reported results from this early monitoring study. These reports discuss the nesting of the armor layer and stabilization as well as the unique dolos structural response measurements. Kendall (1988) reported on design of the unique photogrammetric measurement system using ground-truthed, lowaltitude helicopter, photogrammetric survey techniques as well as the photogrammetric measurements of dolos movements. Baseline surveys were reported. Melby and Turk (1995), Markle et al. (1995), Appleton et al. (1996), Bottin and Tolliver (1999), and Melby (2002) discussed continued monitoring of the dolosse under the Periodic Inspections work unit as well as monitoring specifically for the San Francisco District. Monitoring has included wave climate, dolos movement and breakage, stress measurement within selected dolosse, and coring of dolosse for strength tests. Breakage surveys were conducted using both walking surveys and aerial photography. In order to evaluate fatigue and age effects on concrete strength, core samples were obtained at various locations in the armor layer. These results were reported by Melby (2002).

\section{Monitoring Approach}

The objective of the periodic monitoring of the Crescent City breakwater is to monitor and record dolos movement and structural damage over time. Monitoring the movements of individual, above-water dolosse is achieved through the use of photogrammetric techniques from controlled high-resolution aerial photography, ground surveys, and broken armor unit surveys. The structure is photographed at low tide using ground control targets placed in line to produce 80 percent overlapping 1:360 scale aerial photography. From this, an accurate, permanent record of visible dolosse is created for comparison with past aerial photographs by means of stereoscopic, photogrammetric, compilation instruments. This technique provides precise measurements and reveals any movements of the units. Ground-truth surveys are also conducted to establish the movements of monitoring and control targets and to recondition targets to ensure visibility on photographs. Broken armor unit surveys are conducted by walking the structure to observe and record cracked, broken, and/or displaced dolosse. These methods provide a relatively low-cost means for periodically monitoring concrete armor layers to document structural changes. Instrumented dolosse used in previous Crescent City studies are no longer functional, and thus static stress was not monitored in the most recent inspection.

\section{Goals of Monitoring}

The goals of the present study were to: 
a. Continue monitoring dolos movement with land-based surveying, aerial photography, and photogrammetric analysis to assess long-term stability of dolos armor units on the Crescent City Breakwater.

$b$. Conduct walking broken armor unit survey to assess number of broken dolosse and compare to previous surveys.

In addition to the new movement and breakage data, this report contains comparison to previous movement and breakage data. Also, previously reported concrete strength data are included for supporting documentation. 


\section{Monitoring Results}

\section{Photogrammetric Analysis}

Photogrammetry is a technique in which stereo pairs of aerial photographs with a minimum 80 percent forward overlap are positioned under an instrument called a stereoscope. This allows the image to be viewed in extremely sharp three-dimensional detail. The targeted survey points serve as reference points for overlapping photography. To establish accuracy, comparisons of coordinates for selected ground survey targets with stereo model photographs are conducted (Kendall 1988).

Dolosse are marked with three visible targets at spatially separate points. The photographic analysis is based on an $\mathrm{x}-, \mathrm{y}-$, and z- (easting, northing, and elevation) coordinate system. A dolos centroid (center of mass) can be determined from the xyz coordinates. By establishing current xyz and centroid coordinates, comparisons can be made to past photogrammetric data to determine relative and cumulative linear and rotational movements of selected dolosse. When total relative or cumulative movement of any target meets or exceeds a threshold of 0.15 $\mathrm{m}(0.5 \mathrm{ft})$, it is considered significant and a drawing is generated (Markle et al. 1995).

\section{Targeting and Ground Surveys}

There are 26 dolosse targeted with a total of 70 monitoring targets. Each dolosse was numbered at casting. These numbers are used as unit reference herein. The red dolosse are the structurally instrumented units and they are referred to by letters rather than numbers (e.g., A, B, C...). There are typically three targets per dolosse, except for dolos S, T, U, and V. There are also 27 ground control targets placed in line for use as control. Control targets are identified with alpha-numeric (instrumented units) or numeric codes. For example, in Figure 7A, Targets D1, D2, and D3 are clearly visible on instrumented dolos D in the lower right corner. In Figure 7B, Targets R1, R2, and R3 are visible on the broken instrumented unit R. All targets are above the water line and visible.

These targets were established following the 1986 rehabilitation and have been used since. Proper positioning and accurate surveying of targets is essential to the success of any monitoring plan. Accuracy of ground surveys of control targets was $+/-0.006 \mathrm{~m}(0.02 \mathrm{ft})$. 

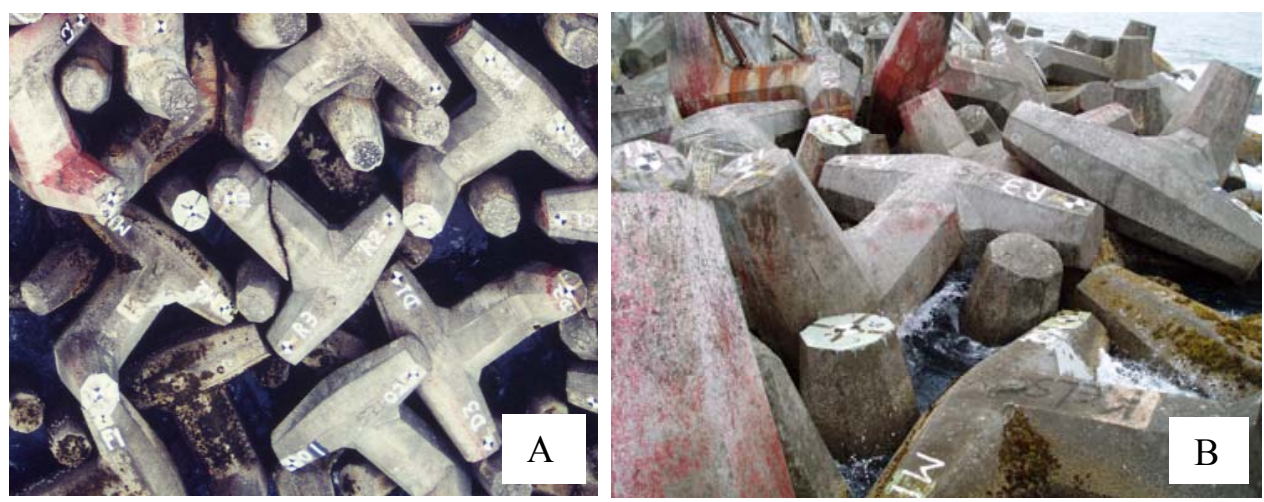

Figure 7. Examples of targets from aerial $(A)$ and ground $(B)$ views

Prior to aerial photography, each target and its identifying character were reconditioned to provide a highly visible contrasting pattern. To ensure accuracy of flight photography and data, the 27 control targets were land-surveyed within 10 days of the flight using California Zone 1 state plane coordinate positions and elevations (NAD27 and NGVD29). Equipment for the ground survey included a Trimble 5600 Robotic Total Station and a Trimble 4800 series global positioning system (GPS).

Ground surveys have been carried out a total of 16 times from 1986 through 2004, with 13 of those during the extensive monitoring period of 1986 through 1993, and the remaining 3 in 1996, 1999, and 2004.

In addition to the targeted units, movement of the non-targeted units was also computed as described in Markle et al. (1995).

\section{Aerial Photography}

Aerial photography is an effective means of capturing images of large areas for later analysis. Visual comparisons and measurements to previous aerial photographs of the same area can be accomplished using stereo pair photography. The method can produce very accurate 3-D images. Due to accurate scaling and extensive detail of modern aerial photography, mapping and surveying can also be accomplished, as discussed above. A Zeiss LMK 1000 aerial mapping camera was mounted on a Bell 47G3B Helicopter and used to obtain images suitable for aerial mapping, surveying, and photographic documentation. A fully analytical stereoplotter was used for photogrammetry. This process is described in detail in Kendall and Melby (1989) and Markle et al. (1995).

\section{Photogrammetry Analysis Results}

Of the 26 targeted dolos units and remaining non-targeted unbroken units, six had movement that exceeded the observation thresholds of $0.15 \mathrm{~m}(0.5 \mathrm{ft})$ cumulatively since 1986. Only dolos A had exceeded the thresholds since 1999. Details of significant movements can be seen in Figures 8-14 and in Table 1. 
However, dolosse A, C, E, and G were recently moved using a crane to verify operation of internal instrumentation (Melby 2002). As such, the movement of these dolosse is not considered significant. Of the remaining dolosse with motion, none had significant movement since 1999.

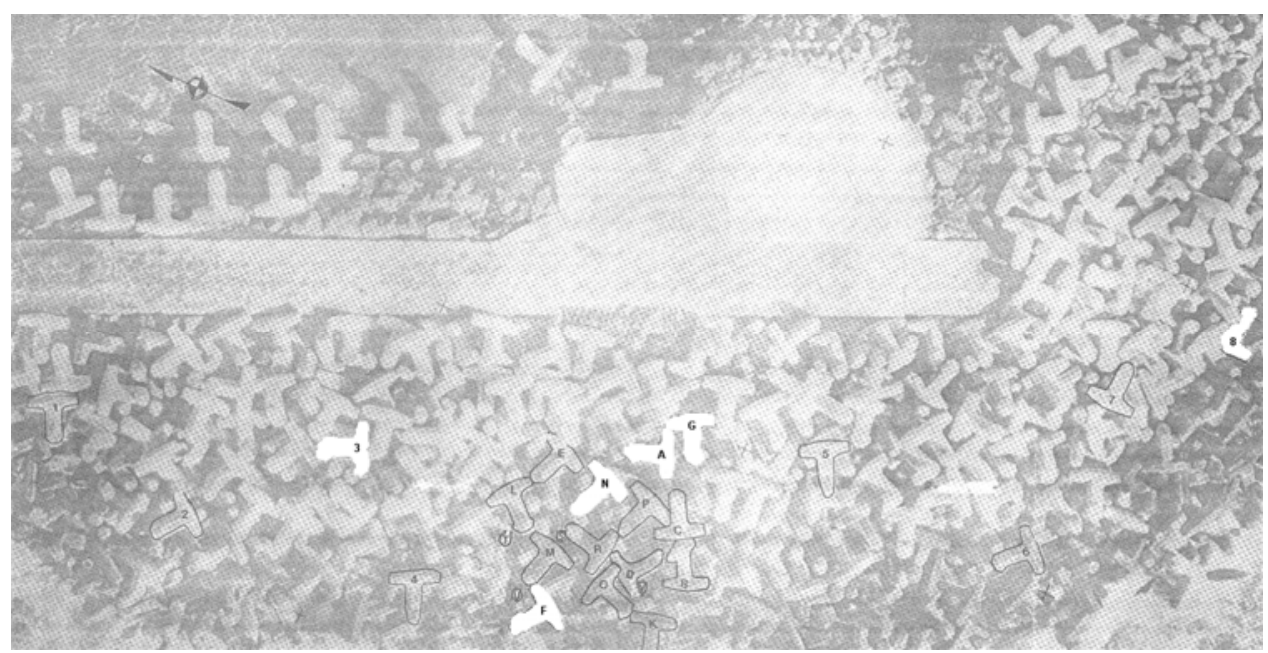

Figure 8. Location of dolosse with significant movement 


\section{Cumulative Movements by Aerial Survey}

\section{Dolos A}

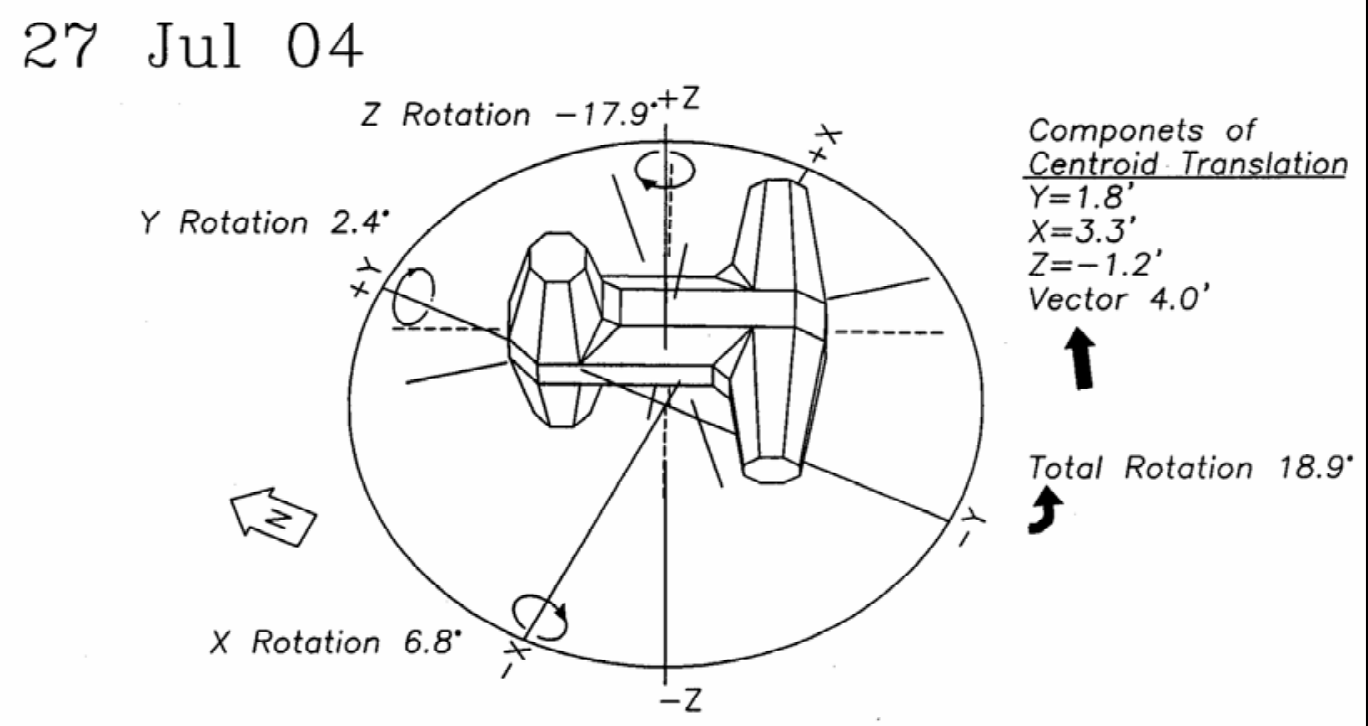

10 Dec 86

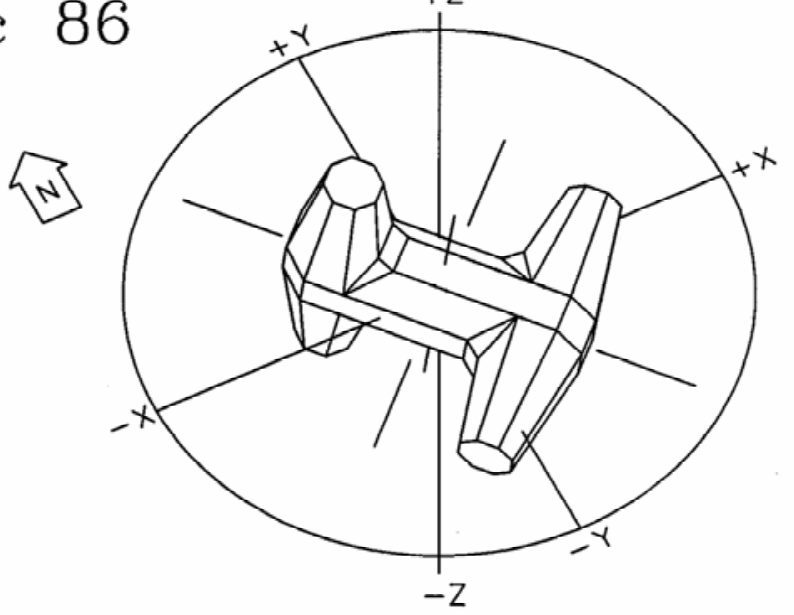

All movement values given are with respect to the State Plane Coordinate system. To emphasize rotation the new (rotated) orientation of the dolos local coordinate system is shown with solid axes; the previous orientation is shown with dashed axes.

Note, as viewed the $X \& Y$ axis rotation directions may appear reversed when the dolos is oriented more than $90^{\circ}$ (about the $Z$ axis) from the reference dolos orientation.

Figure 9. Details of cumulative movement of dolos A through 2004 


\section{Cumulative Movements by Ground Survey}

\section{Dolos F}

30 Jul 04

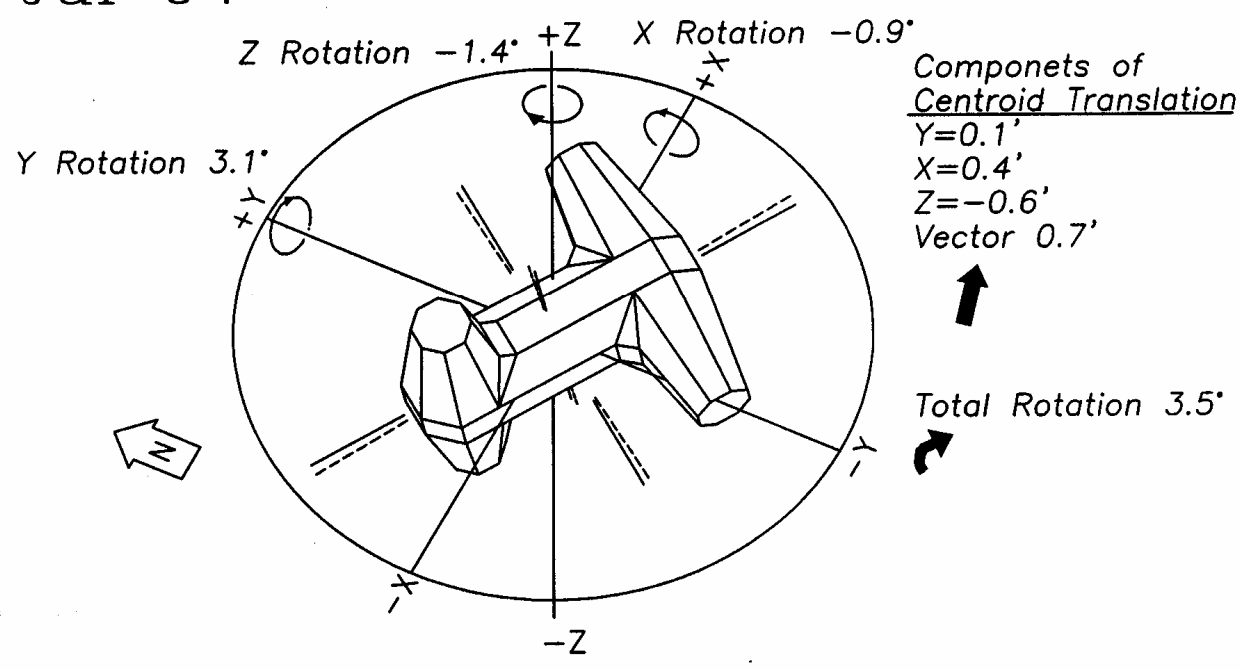

10 Dec 86

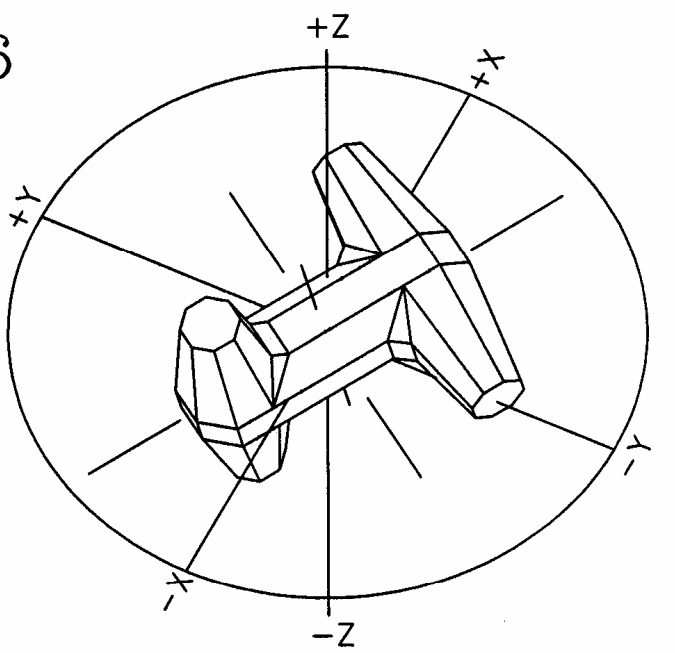

All movement values given are with respect to the State Plane Coordinate system. To emphasize rotation the new (rotated) orientation of the dolos local coordinate system is shown with solid axes; the previous orientation is shown with dashed axes.

Note, as viewed the $X \& Y$ axis rotation directions may appear reversed when the dolos is oriented more than $90^{\circ}$ (about the $Z$ axis) from the reference dolos orientation.

Figure 10. Details of cumulative movement of dolos $F$ through 2004 


\section{Cumulative Movements by Ground Survey}

\section{Dolos G}

30 Jul 04

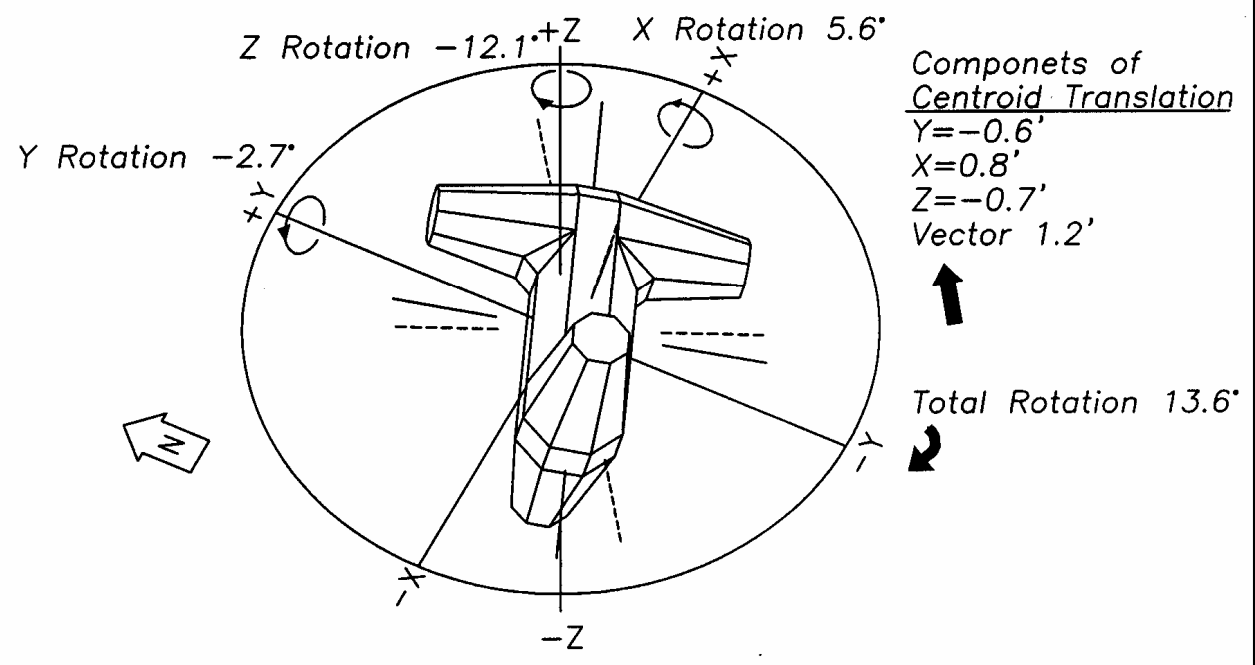

10 Dec 86

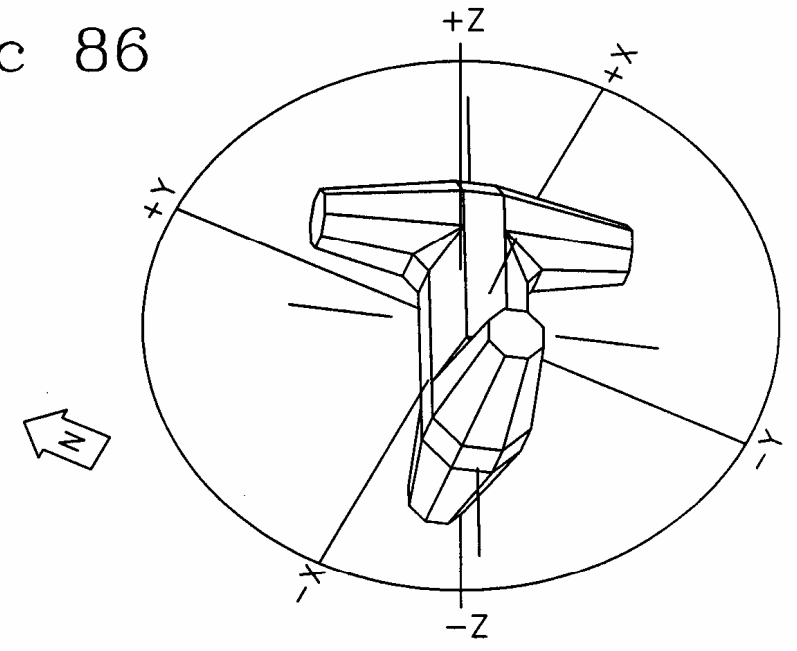

All movement values given are with respect to the State Plane Coordinate system. To emphasize rotation the new (rotated) orientation of the dolos local coordinate system is shown with solid axes; the previous orientation is shown with dashed axes.

Note, as viewed the $X \& Y$ axis rotation directions may appear reversed when the dolos is oriented more than $90^{\circ}$ (about the $Z$ axis) from the reference dolos orientation.

Figure 11. Details of cumulative movement of dolos $\mathrm{G}$ through 2004 


\section{Cumulative Movements by Ground Survey}

\section{Dolos N}

30 Jul 04

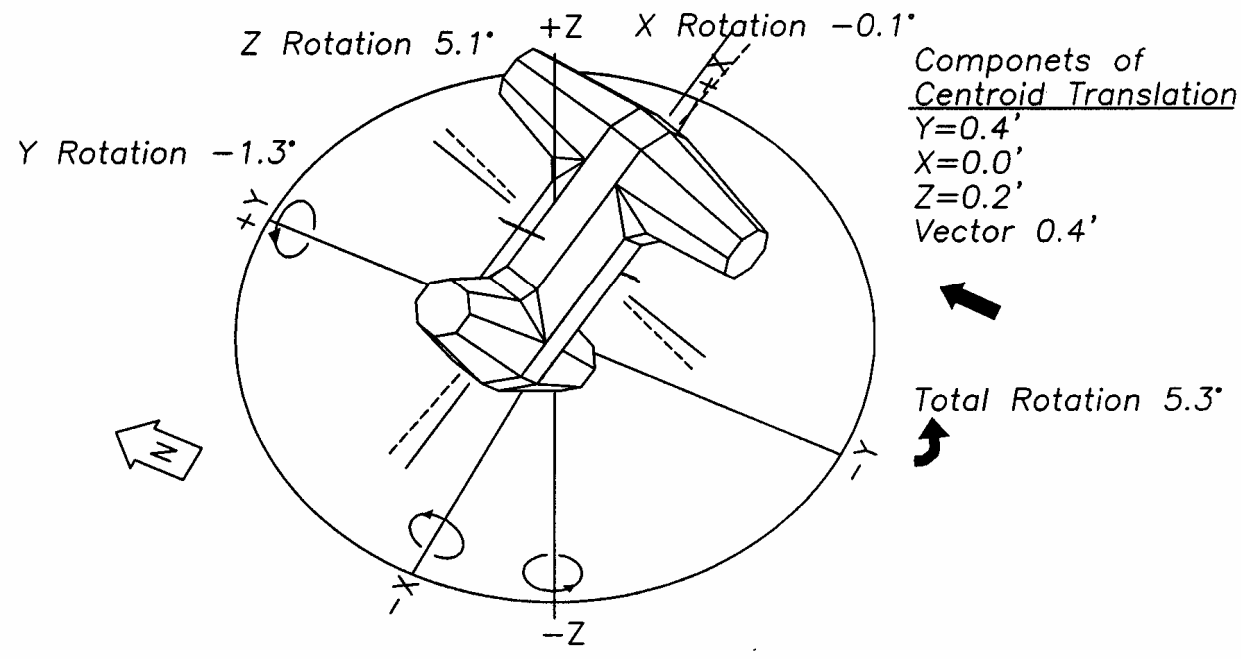

10 Dec 86

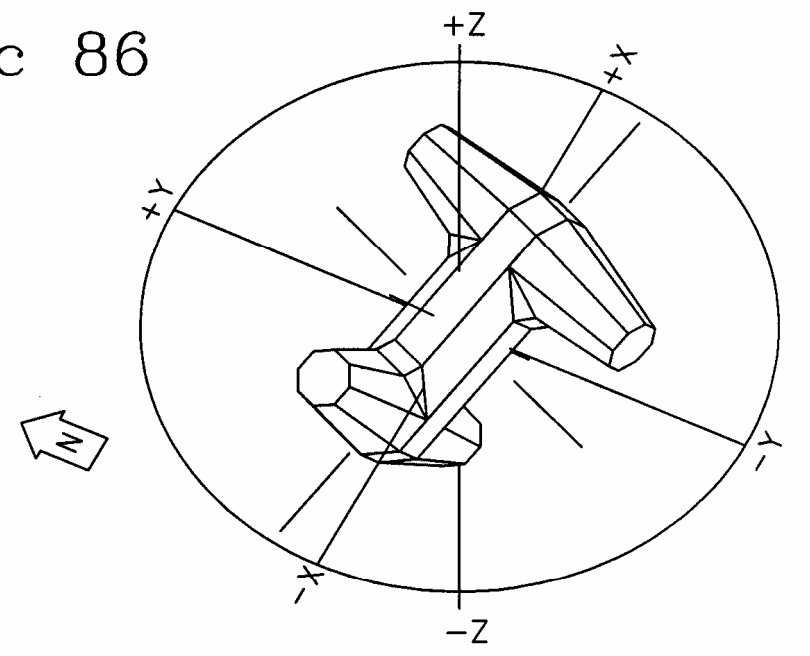

All movement values given are with respect to the State Plane Coordinate system. To emphasize rotation the new (rotated) orientation of the dolos local coordinate system is shown with solid axes; the previous orientation is shown with dashed axes.

Note, as viewed the $X$ \& $Y$ axis rotation directions may appear reversed when the dolos is oriented more than $90^{\circ}$ (about the $Z$ axis) from the reference dolos orientation.

Figure 12. Details of cumulative movement of dolos N through 2004 


\section{Cumulative Movements by Ground Survey}

\section{Dolos 3}

\section{Jul 04}

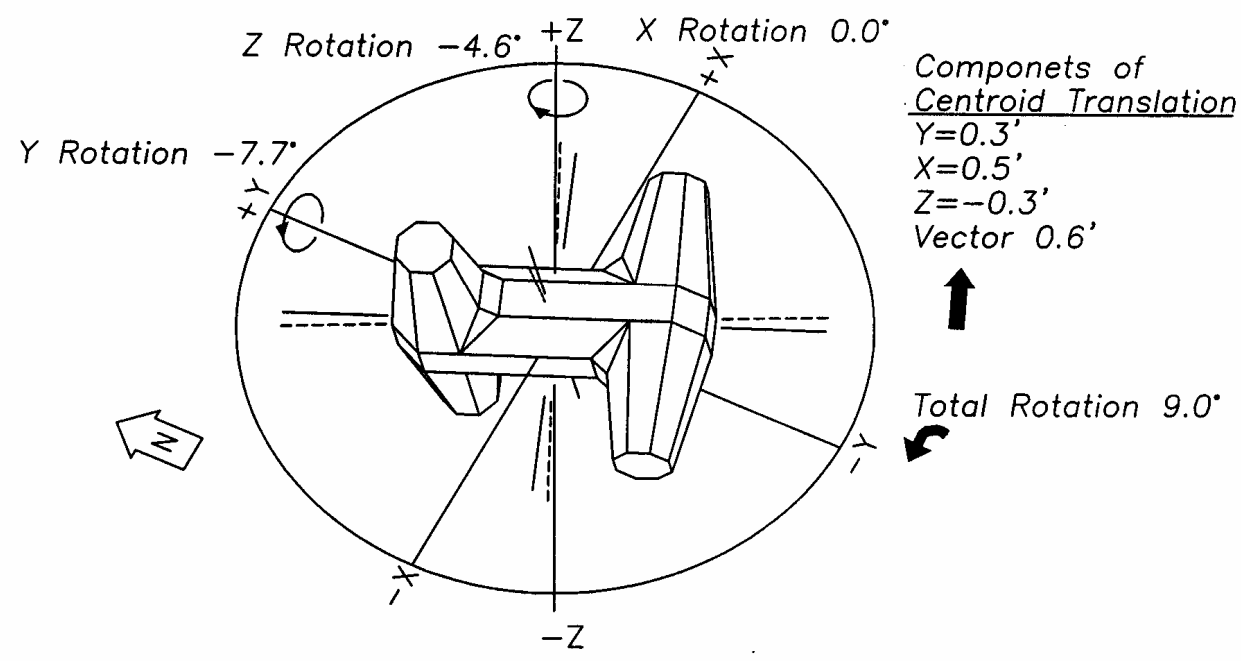

10 Dec 86

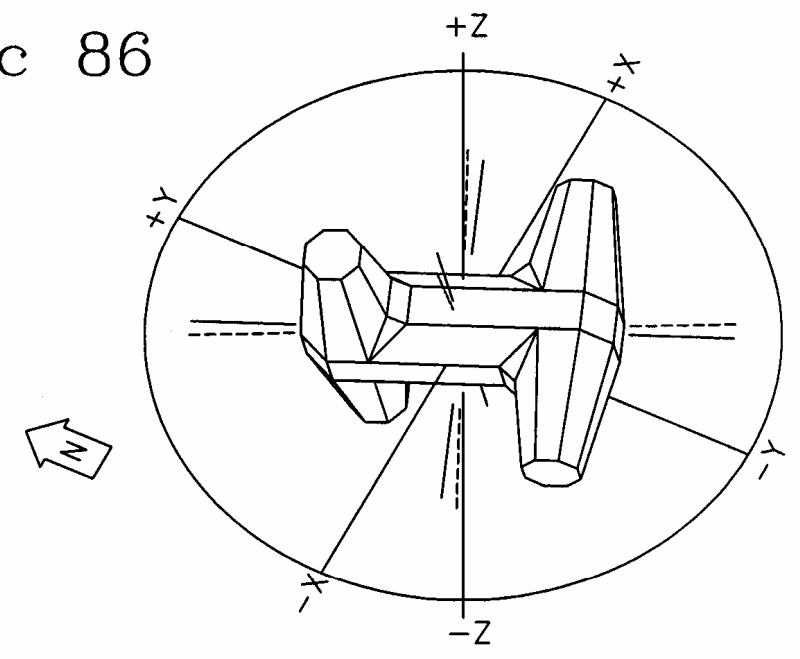

All movement values given are with respect to the State Plane Coordinate system. To emphasize rotation the new (rotated) orientation of the dolos local coordinate system is shown with solid axes; the previous orientation is shown with dashed axes.

Note, as viewed the $X \& Y$ axis rotation directions may appear reversed when the dolos is oriented more than $90^{\circ}$ (about the $Z$ axis) from the reference dolos orientation.

Figure 13. Details of cumulative movement of dolos 3 through 2004 


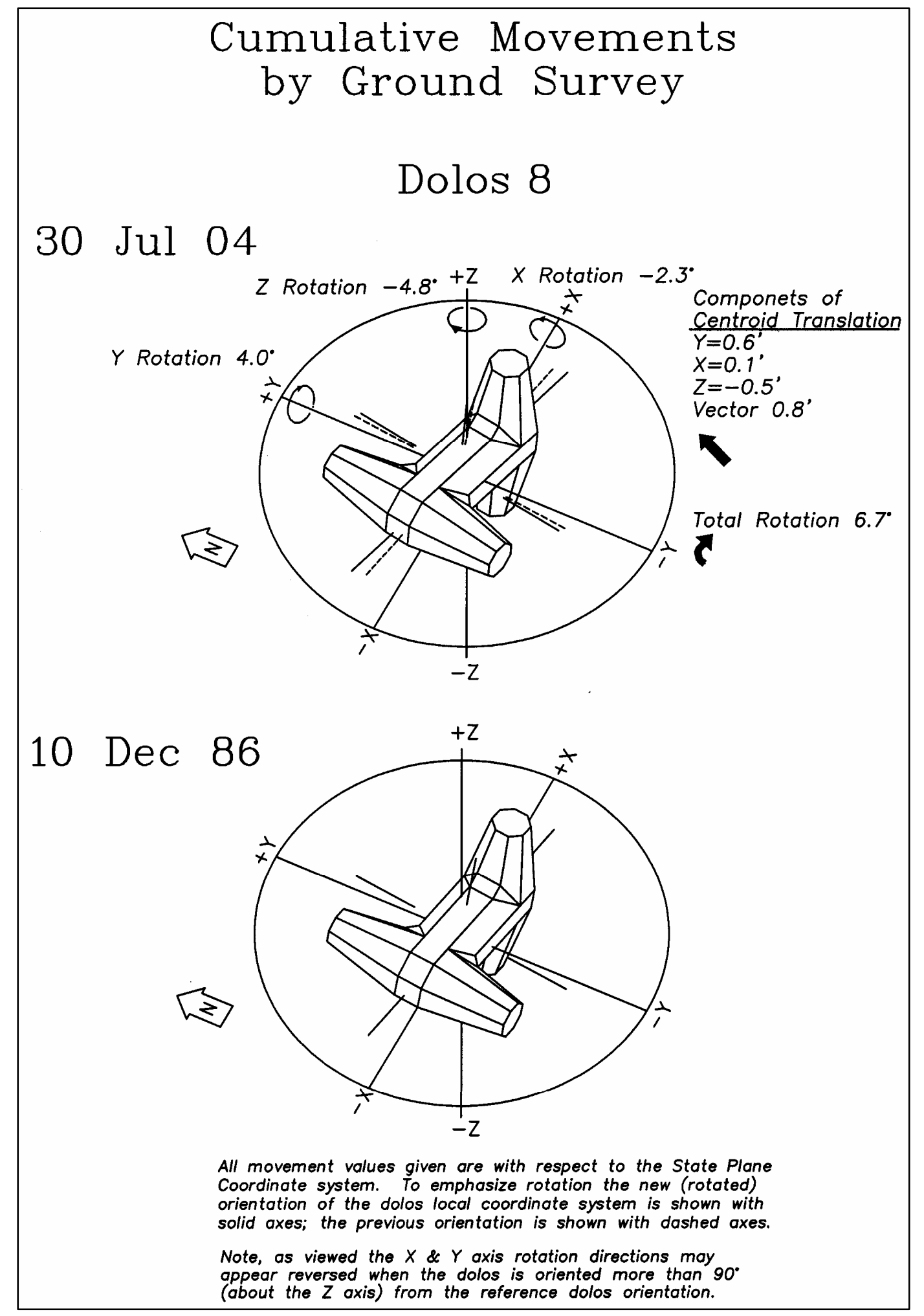

Figure 14. Details of cumulative movement of dolos 8 through 2004 


\begin{tabular}{|c|c|c|c|c|c|c|c|c|c|}
\hline \multicolumn{10}{|c|}{$\begin{array}{l}\text { Table } 1 \\
\text { Significant Movements of Targeted Dolosse Relative to } 1999 \text { and Cumulative from } 1986\end{array}$} \\
\hline \multirow[b]{2}{*}{ Target Dolos Id } & & \multicolumn{4}{|c|}{ Translation m (ft) } & \multicolumn{4}{|c|}{ Rotation Angle (deg) } \\
\hline & & Northing (Y) & Easting (X) & Elev. (Z) & Amp. & $\mathbf{Y}$ & $x$ & $\mathbf{Z}$ & Total \\
\hline \multirow[t]{2}{*}{ Dolos A } & Relative & $0.030(-0.10)$ & $0.23(0.74)$ & $0.02(0.06)$ & $0.23(0.75)$ & -3.3 & 3.0 & 1.8 & 4.8 \\
\hline & Cumulative & $0.56(1.84)$ & $1.02(3.34)$ & $-0.37(-1.17)$ & $1.22(3.99)$ & 2.4 & 6.8 & -17.9 & 18.9 \\
\hline \multirow[t]{2}{*}{ Dolos F } & Relative & $0.003(0.01)$ & $0.02(0.05)$ & $-0.05(-0.16)$ & $0.05(0.17)$ & 1.0 & -0.7 & -0.3 & 1.3 \\
\hline & Cumulative & $0.03(0.10)$ & $0.13(0.42)$ & $-0.17(-0.55)$ & $0.21(0.70)$ & 3.1 & -0.9 & -1.4 & 3.5 \\
\hline \multirow[t]{2}{*}{ Dolos G } & Relative & $-0.07(-0.24)$ & $0.05(0.17)$ & $-0.05(-0.15)$ & $0.10(0.33)$ & -3.3 & -0.3 & -5.8 & 6.7 \\
\hline & Cumulative & $-0.19(-0.62)$ & $0.23(0.76)$ & $-0.22(-0.71)$ & $0.37(1.21)$ & --2.7 & 5.6 & -12.1 & 13.6 \\
\hline \multirow[t]{2}{*}{ Dolos N } & Relative & $0.01(0.03)$ & $0.003(0.01)$ & $-0.01(-0.04)$ & $0.02(0.05)$ & -0.3 & -0.1 & 0.6 & 0.7 \\
\hline & Cumulative & $0.11(0.35)$ & $0.003(0.01)$ & $0.05(0.15)$ & $0.12(0.38)$ & -1.3 & -0.1 & 5.1 & 5.3 \\
\hline \multirow[t]{2}{*}{ Dolos 3} & Relative & $-0.003(-0.01)$ & $0.02(0.08)$ & $-0.03(-0.09)$ & $0.04(0.12)$ & -1.8 & 0.1 & -1.4 & 2.3 \\
\hline & Cumulative & $0.09(0.28)$ & $0.14(0.46)$ & $-0.08(-0.25)$ & $0.18(0.59)$ & \begin{tabular}{|l|}
-7.7 \\
\end{tabular} & 0.0 & -4.6 & 9.0 \\
\hline \multirow[t]{2}{*}{ Dolos 8} & Relative & $0.07(0.22)$ & $0.01(0.04)$ & $-0.06(-0.19)$ & $0.09(0.29)$ & 1.4 & -0.9 & -1.4 & 2.2 \\
\hline & Cumulative & $0.19(0.62)$ & $0.04(0.13)$ & $-0.16(-0.53)$ & $0.25(0.83)$ & 4.0 & -2.3 & -4.8 & 6.7 \\
\hline
\end{tabular}

\section{Broken Armor Unit Survey}

Walking visual inspections of the breakwater were conducted during the month of August or September from 1988 to 2005. Detailed broken armor unit surveys were conducted in 1993 and 2004. In 1993, Melby and Turk (1995) found 14 dolosse broken that were cast in 1986. Of these, 3 appeared to be broken in torsion and the rest in shear or flexure. They also found 33 broken dolosse cast in 1974. Bottin and Tolliver (1999) and Bottin et al. (2004) found no additional breakage over the 1993 survey. However, their surveys were limited to casual observations from on-site and careful comparison with aerial photographs.

A comprehensive broken armor unit survey of above water dolosse was conducted on August 11, 2004, by Messrs. Myrick and Tolliver and Dr. Melby. This inventory revealed a total of 50 visible broken dolosse of which 14 were cast in 1986 and 36 were cast in 1974. Overall, 33 dolosse were broken at the shankfluke interfaces (Figures 15 and 16), seven along the shank (Figure 17), two in the fluke, and eight dolosse were broken into 2 or more pieces. The break descriptions of fluke-shank and shank-fluke are intended to differentiate between a break that is primarily in the fluke from one that is primarily in the shank, respectively. The broken dolos inventory, along with the location of broken dolosse and detailed types of breaks are listed in Table 2 and Figures 18-20. The results of the survey show that there has been no additional breakage since the last detailed comprehensive armor unit survey in 1993 by Melby and Turk. 


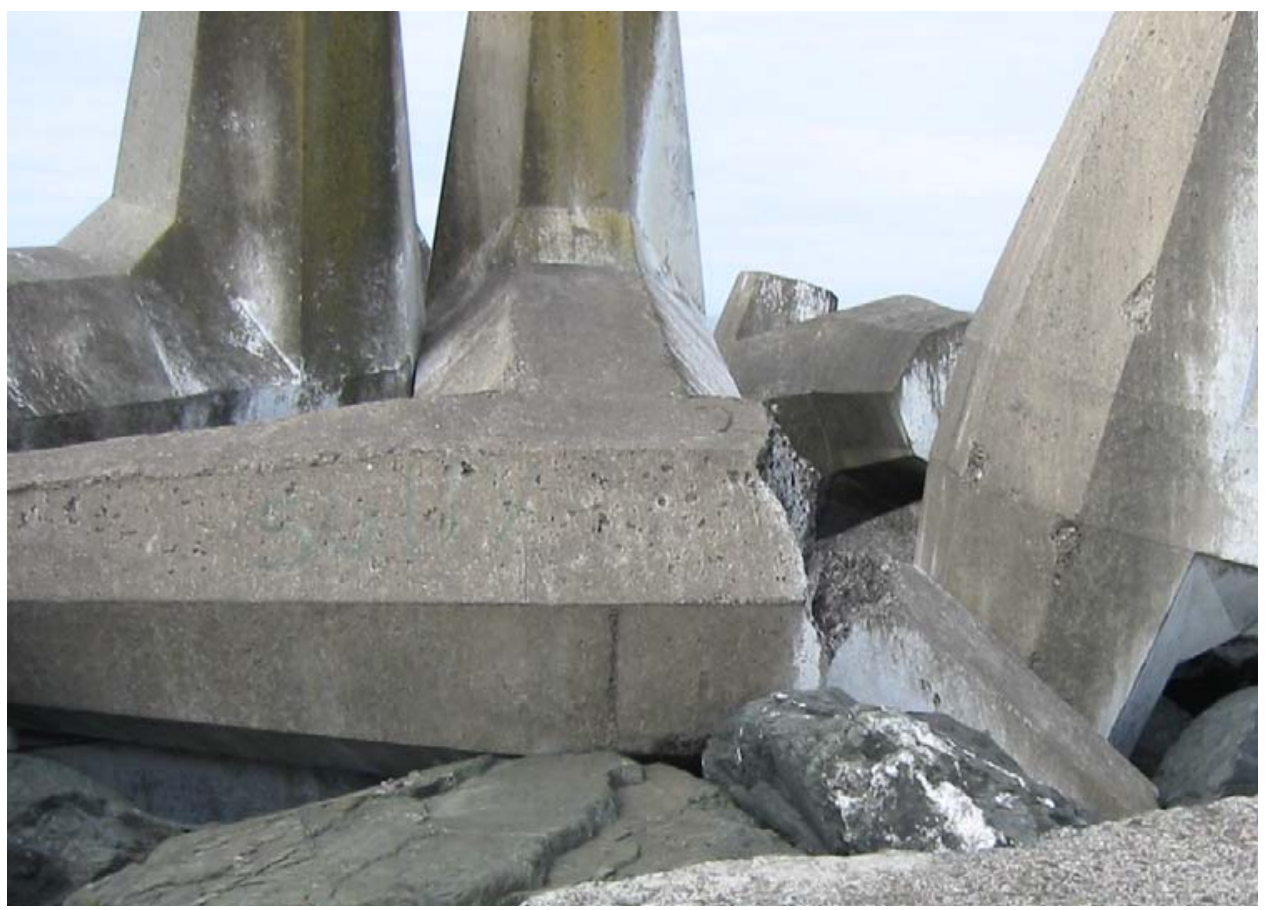

Figure 15. Example of a straight fluke-shank dolos break

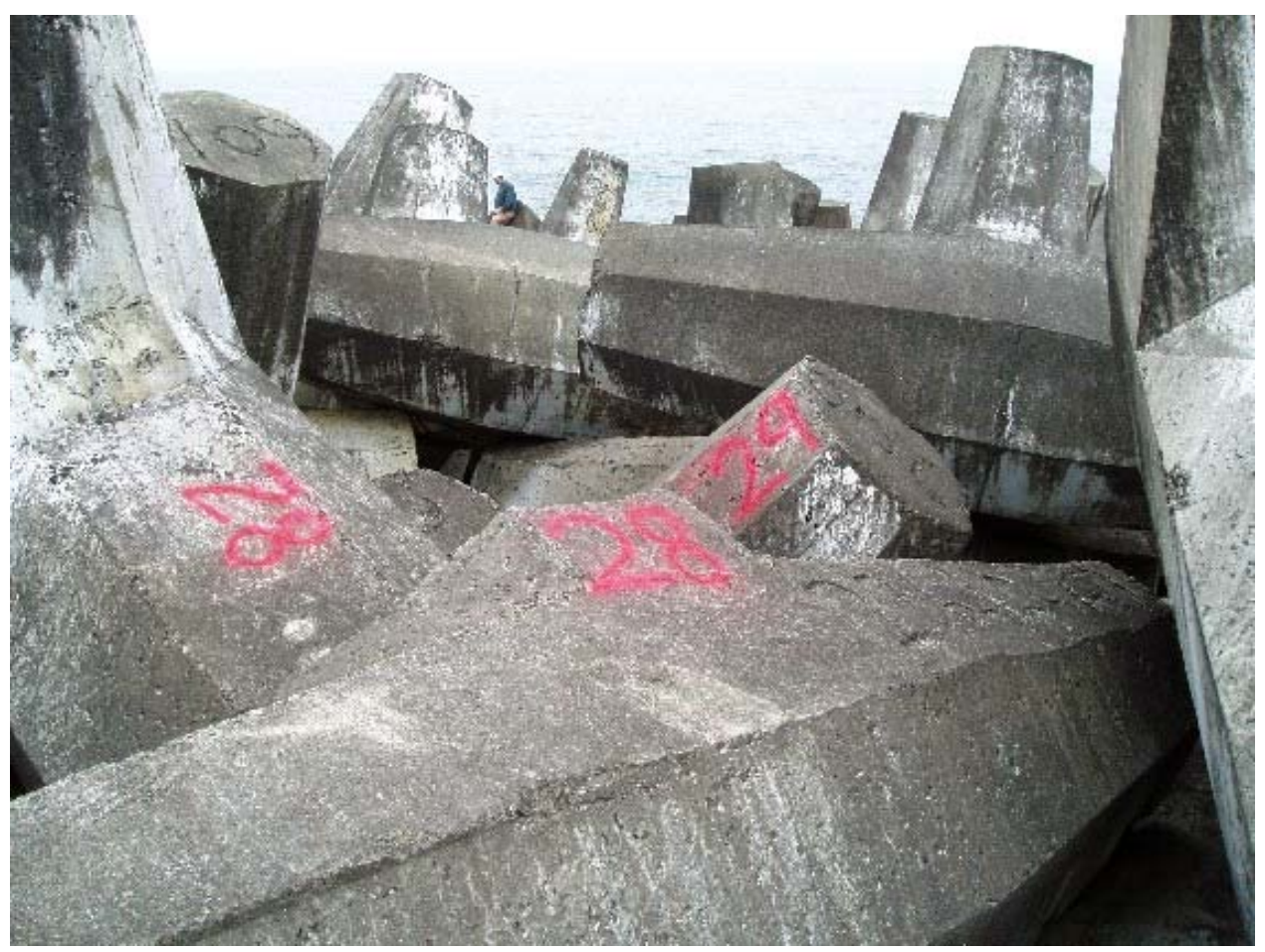

Figure 16. Example of shank-fluke dolos break 


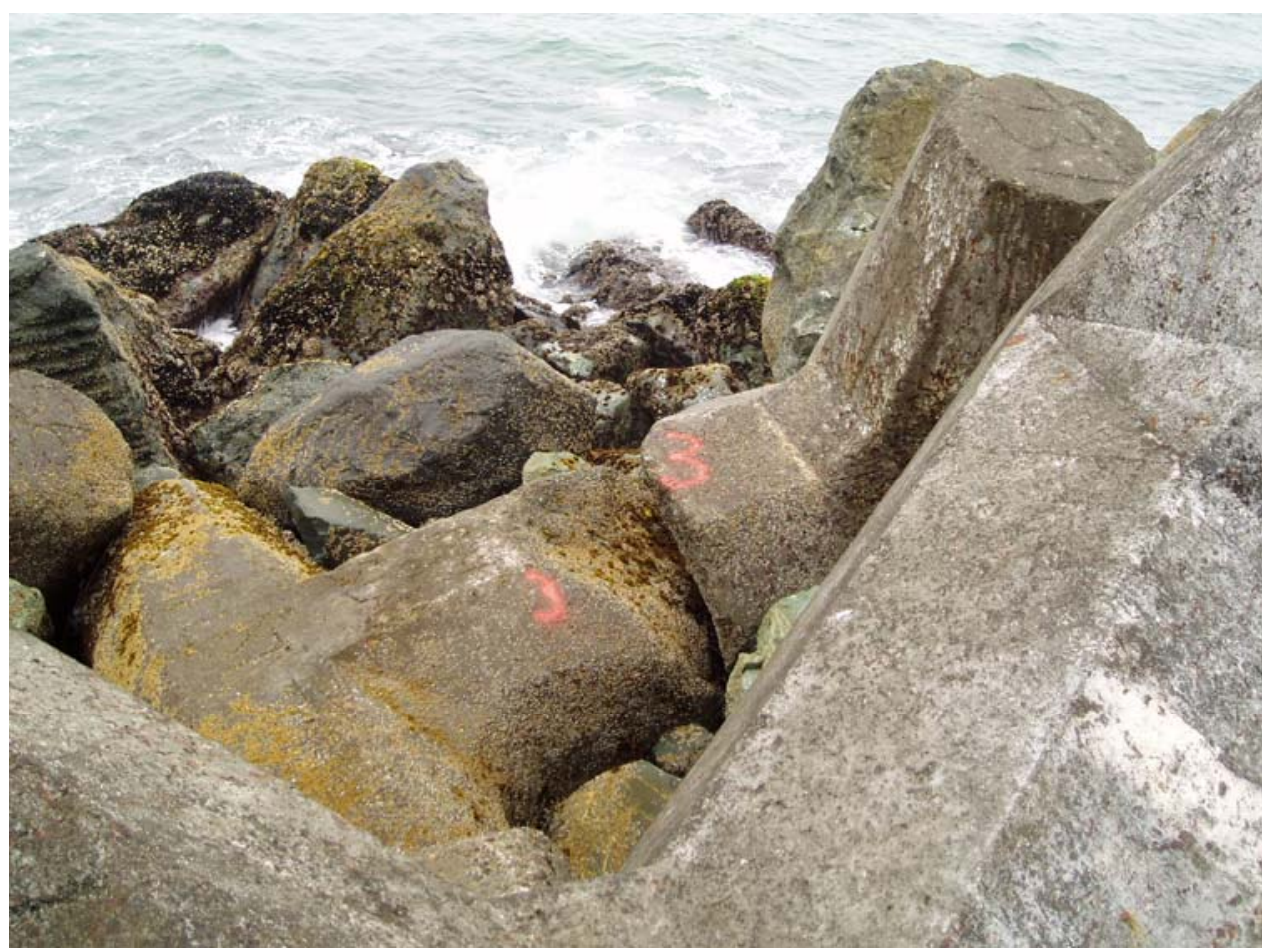

Figure 17. Example of mid-shank dolos break

\begin{tabular}{|l|l|l|l|l||}
\hline $\begin{array}{l}\text { Table 2 } \\
\text { Broken Dolos Inventory Data }\end{array}$ \\
\hline \hline $\begin{array}{l}\text { Dolos Photo } \\
\text { Log No. }\end{array}$ & $\begin{array}{l}\text { Station } \\
\text { No. }\end{array}$ & $\begin{array}{l}\text { Year } \\
\text { Placed }\end{array}$ & $\begin{array}{l}\text { Offset from Center line } \\
\text { on Ocean Side, m (ft) }\end{array}$ & Type of Break, Comments \\
\hline \hline 1 & $34+50$ & 1986 & $13.11(43)$ & Pieces \\
\hline 2 & $34+40$ & 1986 & $16.76(55)$ & $\begin{array}{l}\text { Straight fluke-shank and } \\
\text { straight shank-fluke breaks }\end{array}$ \\
\hline 3 & & & & Straight mid-shank break \\
\hline 4 & $34+22$ & 1986 & $18.29(60)$ & Straight fluke-shank break \\
\hline 5 & $34+57$ & 1974 & $6.10(20)$ & Straight shank-fluke break \\
\hline 6 & $34+84$ & 1974 & $10.67(35)$ & 3 pieces \\
\hline 7 & $34+94$ & 1974 & $14.33(47)$ & Straight shank-fluke break \\
\hline 8 & $34+94$ & 1974 & $11.58(38)$ & Torque angle shank break \\
\hline 9 & $35+07$ & 1974 & $11.58(38)$ & Straight fluke-shank break \\
\hline 10 & $35+02$ & 1974 & $11.28(37)$ & Pieces \\
\hline 11 & $35+00$ & 1974 & $14.94(49)$ & Straight shank-fluke break \\
\hline 12 & $35+14$ & 1974 & $12.50(41)$ & Straight shank-fluke break \\
\hline 13 & $34+94$ & 1974 & $6.10(20)$ & Straight fluke-shank break \\
\hline 14 & $35+31$ & 1974 & $11.28(37)$ & $\begin{array}{l}\text { Straight shank-fluke } \\
\text { crack/break }\end{array}$ \\
\hline 15 & $35+44$ & 1974 & $12.80(42)$ & Straight shank-fluke break \\
\hline 16 & $35+49$ & 1974 & $6.71(22)$ & Angled shank-fluke break \\
\hline 17 & $35+58$ & 1974 & $5.49(18)$ & Straight fluke-shank break \\
\hline 18 & $35+79$ & 1974 & $6.10(20)$ & Straight fluke-shank break \\
\hline 19 & $35+50$ & 1974 & $9.45(31)$ & Straight shank-fluke break \\
\hline \hline & $35+75$ & 1974 & $4.57(15)$ & Continued) \\
\hline & & & & \\
\hline
\end{tabular}




\begin{tabular}{|c|c|c|c|c|}
\hline $\begin{array}{l}\text { Dolos Photo } \\
\text { Log No. }\end{array}$ & \begin{tabular}{|l|} 
Station \\
No. \\
\end{tabular} & \begin{tabular}{|l|} 
Year \\
Placed
\end{tabular} & $\begin{array}{l}\text { Offset from Center line } \\
\text { on Ocean Side, } m \text { (ft) }\end{array}$ & Type of Break, Comments \\
\hline 20 & $35+23$ & 1986 & $21.95(72)$ & Straight fluke-shank break \\
\hline 21 & $35+33$ & 1986 & $30.48(100)$ & Angled fluke break \\
\hline 22 & $35+55$ & 1986 & $32.92(108)$ & Straight fluke-shank break \\
\hline 23 & $35+95$ & 1986 & $23.77(78)$ & Angled shank break \\
\hline 24 & $36+30$ & 1974 & $4.57(15)$ & Straight mid-shank break \\
\hline 25 & $36+22$ & 1974 & $6.10(20)$ & Pieces \\
\hline 26 & $36+16$ & 1974 & $5.49(18)$ & Straight mid-shank break \\
\hline 27 & $36+11$ & 1974 & $5.49(18)$ & Straight fluke-shank break \\
\hline 28 & $36+42$ & 1974 & $6.10(20)$ & Straight shank-fluke break \\
\hline 29 & $36+36$ & 1974 & $9.45(31)$ & Straight shank-fluke break \\
\hline 30 & $36+30$ & 1974 & $9.14(30)$ & Straight shank-fluke break \\
\hline 31 & $36+42$ & 1974 & $8.53(28)$ & Straight shank-fluke break \\
\hline 32 & $36+36$ & 1974 & $7.62(25)$ & Torque pieces \\
\hline 33 & $36+60$ & 1986 & $26.52(87)$ & Angled shank-fluke break \\
\hline 34 & $36+70$ & 1986 & $23.77(78)$ & Straight fluke-shank break \\
\hline 35 & $36+78$ & 1986 & $24.38(80)$ & Fluke break \\
\hline 36 & $36+79$ & 1986 & $9.75(32)$ & Straight shank-fluke break \\
\hline 37 & $36+80$ & 1974 & $17.37(57)$ & Straight mid-shank break \\
\hline 38 & $36+72$ & 1974 & $15.24(50)$ & Straight mid-shank break \\
\hline 39 & $36+64$ & 1974 & $13.72(45)$ & Straight shank break \\
\hline 40 & $37+15$ & 1974 & $10.06(33)$ & Straight fluke-shank break \\
\hline 41 & $37+04$ & 1974 & $11.58(38)$ & Pieces \\
\hline 42 & $36+74$ & 1974 & $13.11(43)$ & Straight shank-fluke break \\
\hline 43 & $37+31$ & 1974 & $18.29(60)$ & Straight fluke-shank break \\
\hline 44 & $37+40$ & 1986 & $6.10(20)$ & Straight fluke-shank break \\
\hline 45 & $37+48$ & 1974 & $22.25(73)$ & Angled shank break \\
\hline 46 & $37+40$ & 1986 & $24.99(82)$ & Straight shank-fluke break \\
\hline 47 & $37+39$ & 1974 & $14.33(47)$ & Pieces \\
\hline 48 & $37+39$ & 1974 & $15.85(52)$ & Straight mid-shank break \\
\hline 49 & $37+43$ & 1974 & $14.63(48)$ & Straight fluke-shank break \\
\hline 50 & $37+20$ & 1986 & $32.00(105) \mathrm{NE}$ & Straight fluke-shank break \\
\hline
\end{tabular}




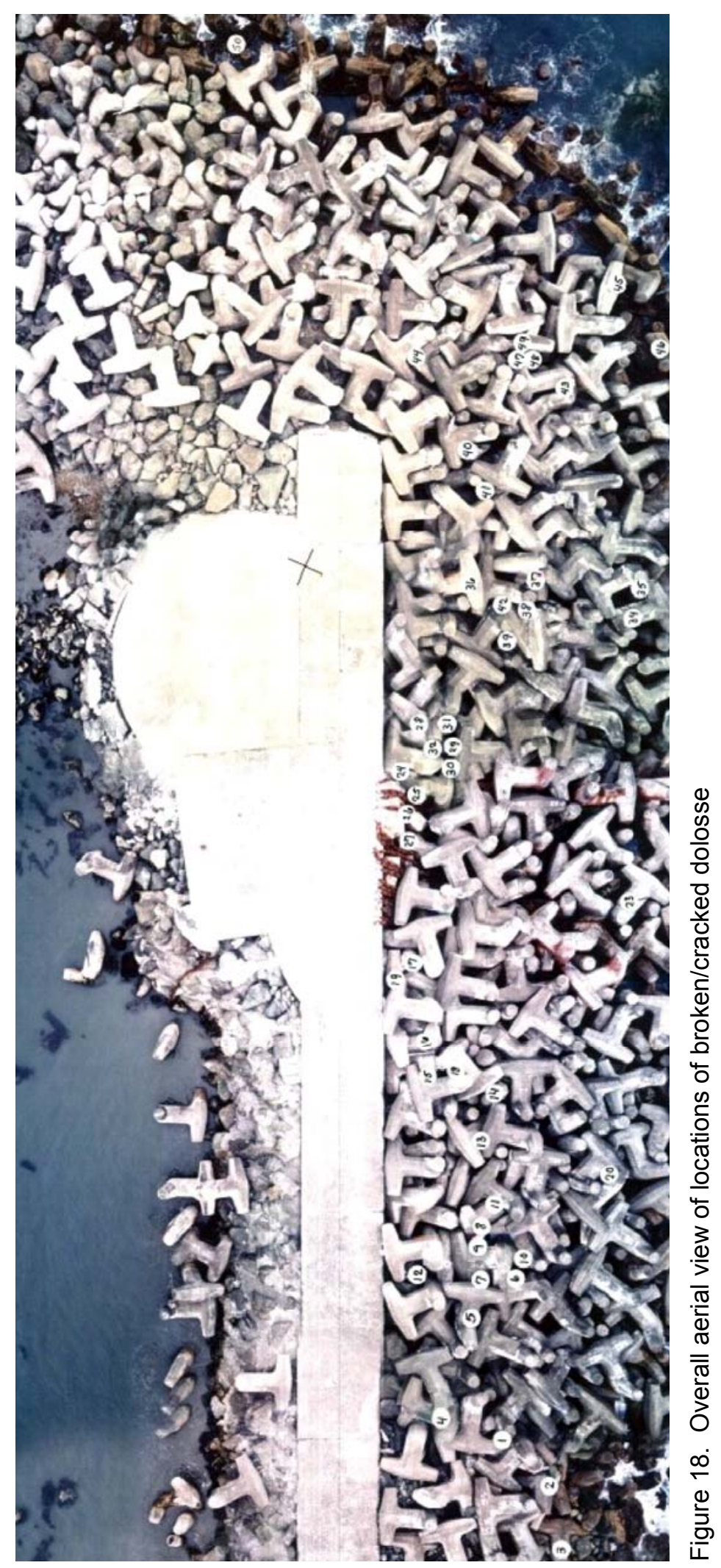




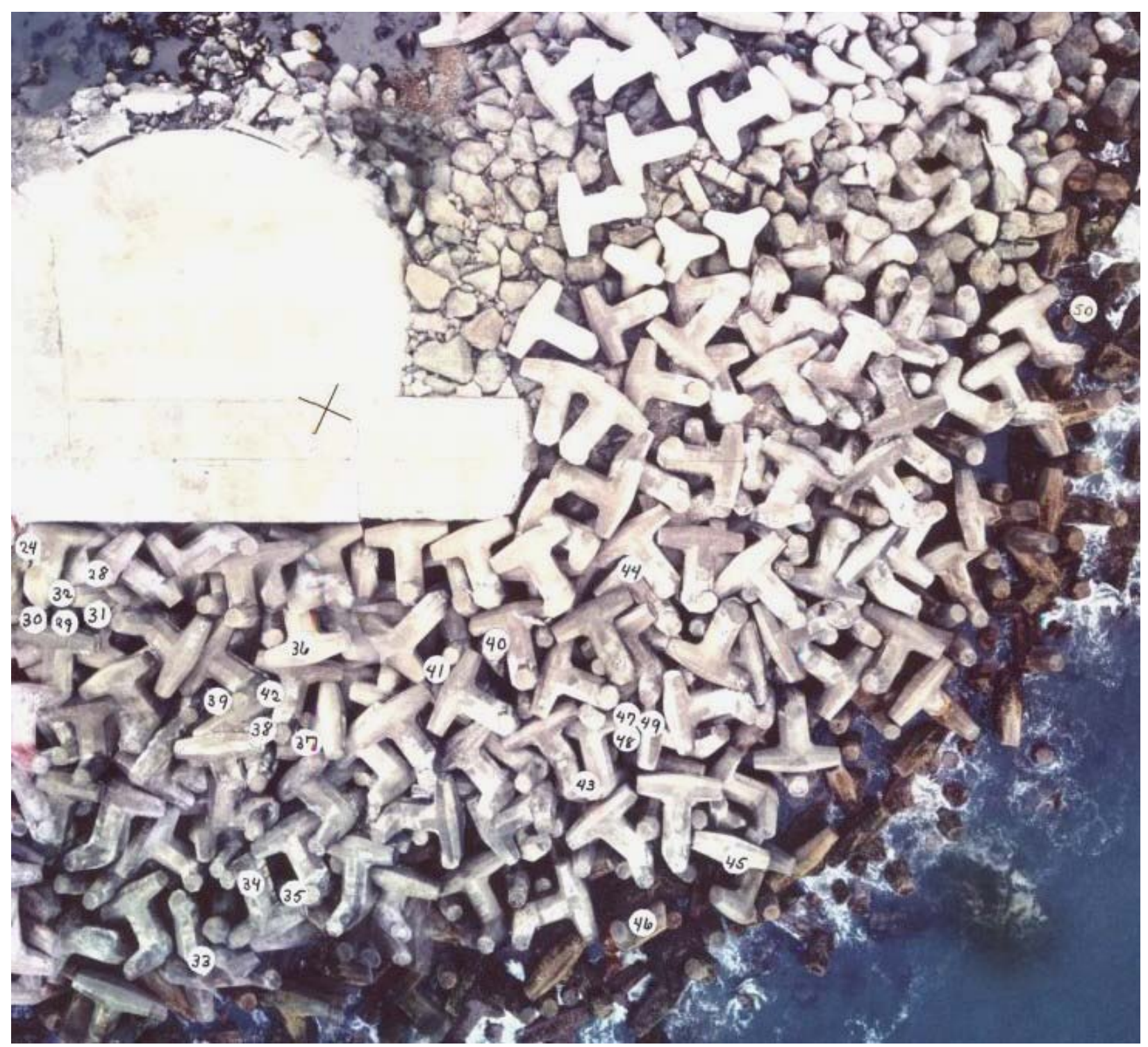

Figure 19. Locations of broken/cracked dolosse along the southerly portion of elbow 


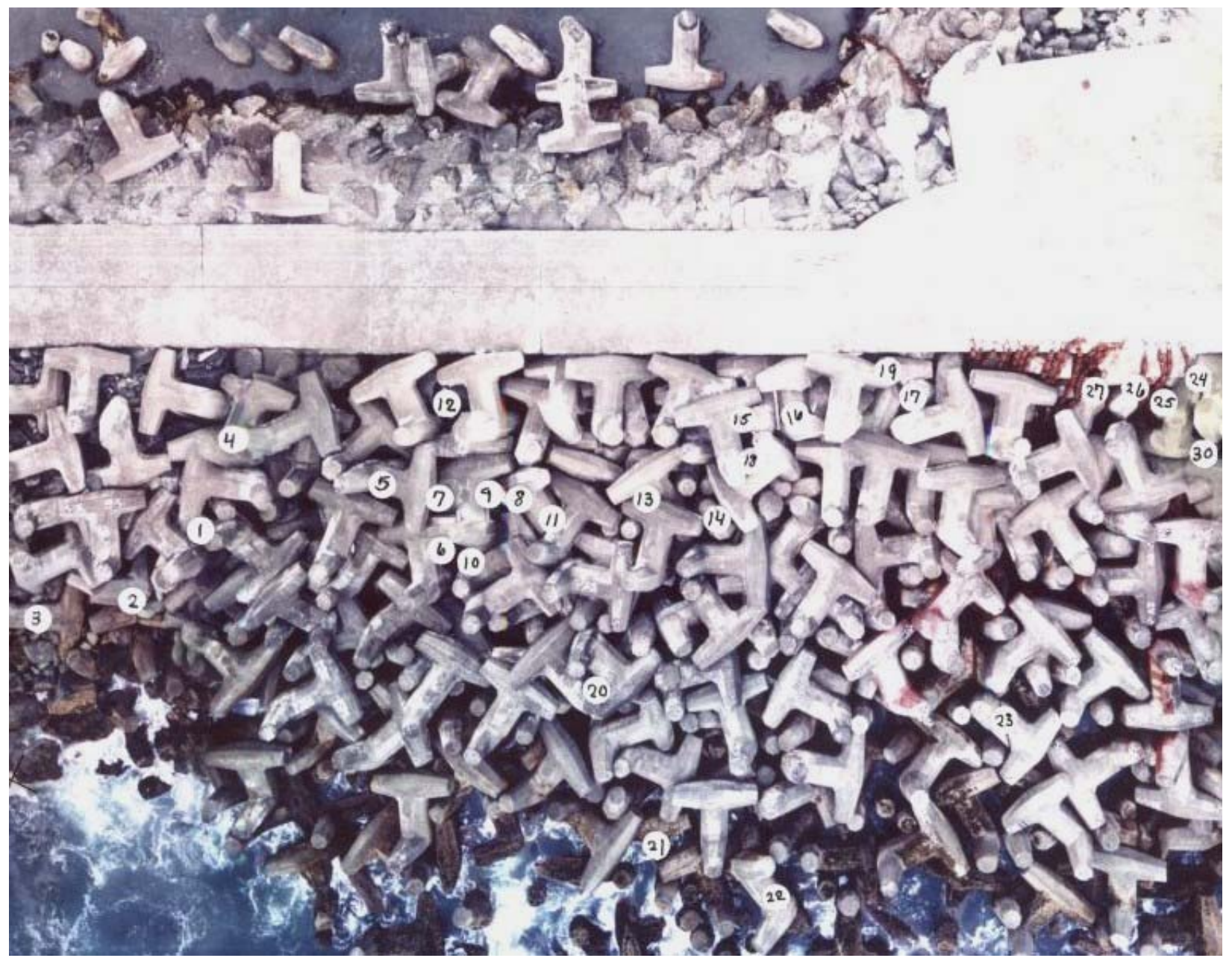

Figure 20. Locations of broken/cracked dolosse along the notherly portion of the elbow

\section{Concrete Strength Tests}

Concrete strength tests were conducted during construction of the 1986 rehabilitation. The average 28-day modulus of rupture or flexural strength of the concrete used for the 1986 dolosse was very high at $6.8 \mathrm{MPa}$ (986 psi) (Melby 2002). The standard deviation was $0.41 \mathrm{MPa}$ (59 psi). Note that the concrete was reinforced with crimped 2-in-long metal fibers. For comparison, the unreinforced 28-day flexural strength was $6.48 \mathrm{MPa}$ (940 psi). Therefore, the fibers produced a five percent increase in flexural strength.

In August 1995, core samples were obtained from two 1986 dolosse near the cap to determine how the concrete strength had changed as the dolosse aged under repeated loading during the ten years since construction. Core samples were also obtained from one 1974 dolos for comparison of strengths. The 1974 dolos used for coring was a broken unit near the cap and two cores were taken very near the break. In August 1999, core samples were obtained from dolosse just above the still water level. The locations of cored units are shown Figure 21. 


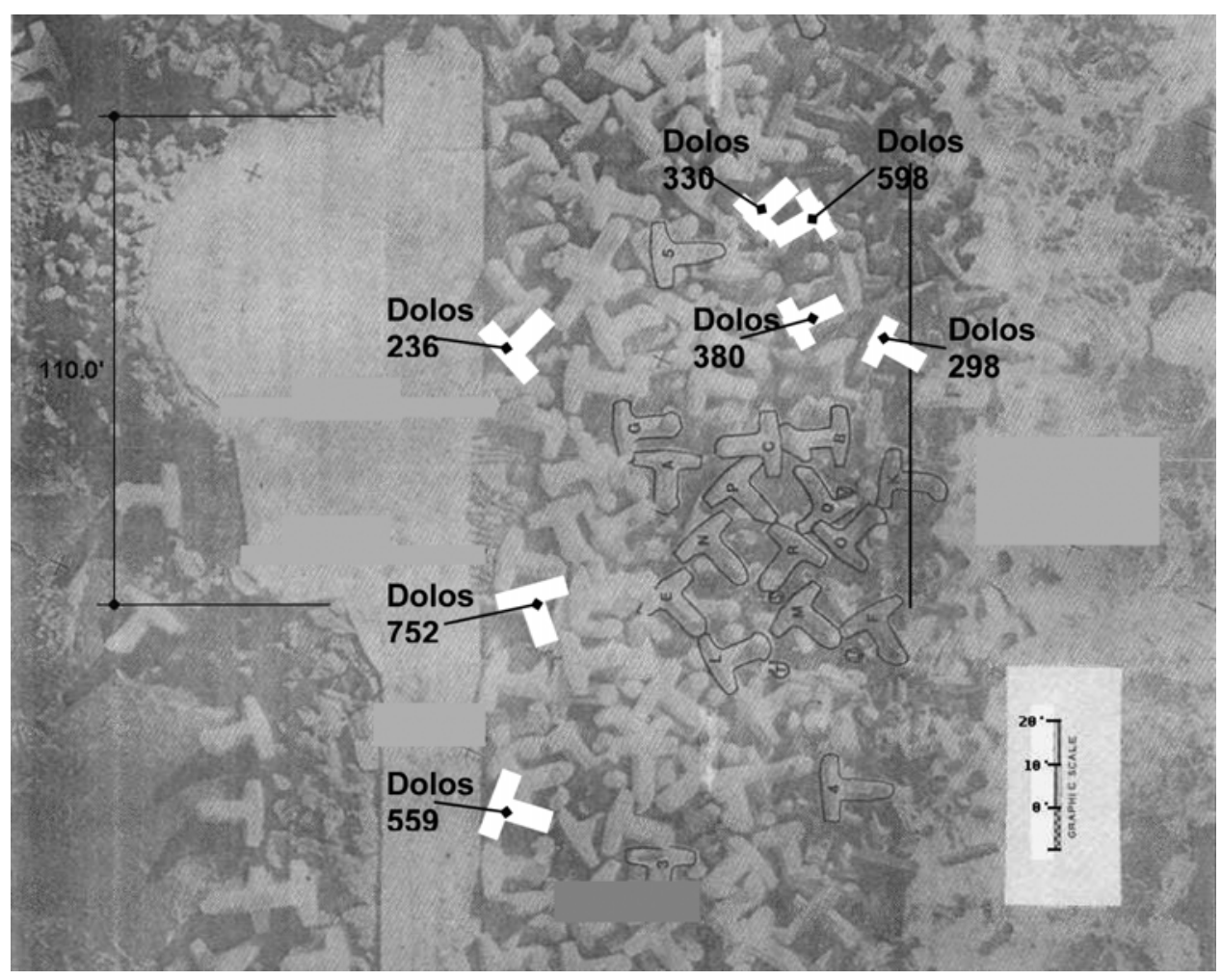

Figure 21. Location of cored dolosse

Melby (2002) reported two tools developed to test the concrete strength in situ. The basic idea behind the tool development was to be able to break small shallow cores in the field and determine the rupture strength from the load required to break the cores. This testing represents a compromise between the non-destructive strength testing tools, such as a Schmidt hammer, which are not accurate, and typical destructive testing which requires $15-\mathrm{cm}(6-\mathrm{in}$.) cores to be drilled over $0.3 \mathrm{~m}(1 \mathrm{ft})$ deep, broken off, and returned to a certified laboratory for controlled testing. The two tools were simply adapters allowing a torque wrench to be connected to the tip of a 7.6-cm (3-in.) diameter core. One tool permitted the load to be applied in flexure and the other in torsion. A shallow 2-cm diameter hole was drilled in the center of each core to accept the fixture.

A total of 20 cores were obtained. Seven of these cores were broken with the in situ strength analysis tools. A drill bit with diameter $7.6 \mathrm{~cm}$ (3 in) was used producing samples with nominal diameters of $6.67 \mathrm{~cm}$ (2.625 in). In 1999, seven cores were obtained in the traditional manner from four dolosse, with one being cast in 1974 and the rest cast in 1986. All 1999 cores were drilled with a $10.2 \mathrm{~cm}$ (4 in) diameter bit producing a nominal sample diameter of $9.21 \mathrm{~cm}$ (3.625 in). All cores were returned to the WES concrete laboratory and subjected to traditional compressive and tensile testing, after being prepared in accordance with ASTM C-42, ASTM C-39, and ASTM C-78. Table 3 shows the results of the core testing. The compressive tests were done in accordance with ASTM C-39, the splitting in accordance with ASTM C-496, and the flexure in accordance with ASTM C-293. For the flexural tests, the loading was three points with bottom span length of three times the diameter. The loading rate for the compressive 
tests was $53.4 \mathrm{kN} / \mathrm{min}$ (12 kip/min), splitting was $15.6 \mathrm{kN} / \mathrm{min}$ (3.5 kip/min), and the flexural was $0.667 \mathrm{kN} / \mathrm{min}(0.15 \mathrm{kip} / \mathrm{min})$. The flexural strength was determined using simple beam theory as $f_{r}{ }_{r}=8 P L / \pi d^{3}$ where $P$ is the applied load, $L$ is the bottom span length, and $d$ the specimen diameter.

Several observations can be made regarding the strengths listed in Table 3. First, the concrete strength has increased substantially for both the 1986 dolosse and the 1974 dolosse, as expected. In 1995, the average compressive strength for the 1986 dolosse was $62.76 \mathrm{MPa}(9,100 \mathrm{psi})$, the flexural was $10.08 \mathrm{MPa}(1,461$ psi), and the splitting was $3.90 \mathrm{MPa}(565 \mathrm{psi}$ ) (not counting the obvious outlier of 2.1 $\mathrm{MPa}(310 \mathrm{psi})$ ). This compares with the 198628 -day flexural strength from beams of $6.8 \mathrm{MPa}$ (986 psi). Secondly, the splitting strength was less than half the flexural strength. This is significantly less than predicted by ACI formulae. Contributing to the difference is the fact that the test was non-standard, being done using cylinders rather than beams. Third, the splitting strength was less than the usual estimate of one-tenth the compressive strength while the flexural strength was substantially higher than this. The average splitting strength was 6 percent of the compressive, while the flexural strength was 16 percent of the compressive. Finally, the flexural testing tool developed under this project seemed to predict the flexural strength reasonably well, considering the scatter in the ASTM standard tests. This is encouraging and perhaps warrants further investigation.

To illustrate the increase in strength, Figures 22 and 23 show the compressive and tensile strengths for all dolosse, respectively. Figure 22 shows the compressive strength results as a function of age for dolosse near the cap and near the still water level. Figure 23 shows the flexural tensile strength results as a function of age for dolosse near the cap, near the still water level, and for all 1986 dolosse at casting time (dashed line). Here, age is used on the horizontal axis to separate the 1986 dolosse from the 1974 units and not to show a general trend. Figures 22 and 23 highlight several interesting points concerning the Crescent City dolos concrete. First, the concrete strength in these units was very high. Typically, concrete armor units are specified to have minimum 28-day compressive and flexural tensile strengths of approximately $35 \mathrm{Mpa}$ and $3.5 \mathrm{Mpa}$, respectively. The measured strengths were more than double this specification. All 1986 dolosse tested show increased strengths over the as-built average value of $6.8 \mathrm{Mpa}$. The range of increase is from 9 percent to 76 percent, with the lowest increase being in the most heavily loaded units near the low water level. The mean strength increase of the cap units corresponds crudely to the theoretical increase in strength with time. The units near the low water level show significantly lower strength levels than the units near the cap. This lower strength level could be due to fatigue. A crude theoretical estimate showed that this was the most likely cause; but the reduced strength levels are still greater than the 28-day strength levels. 


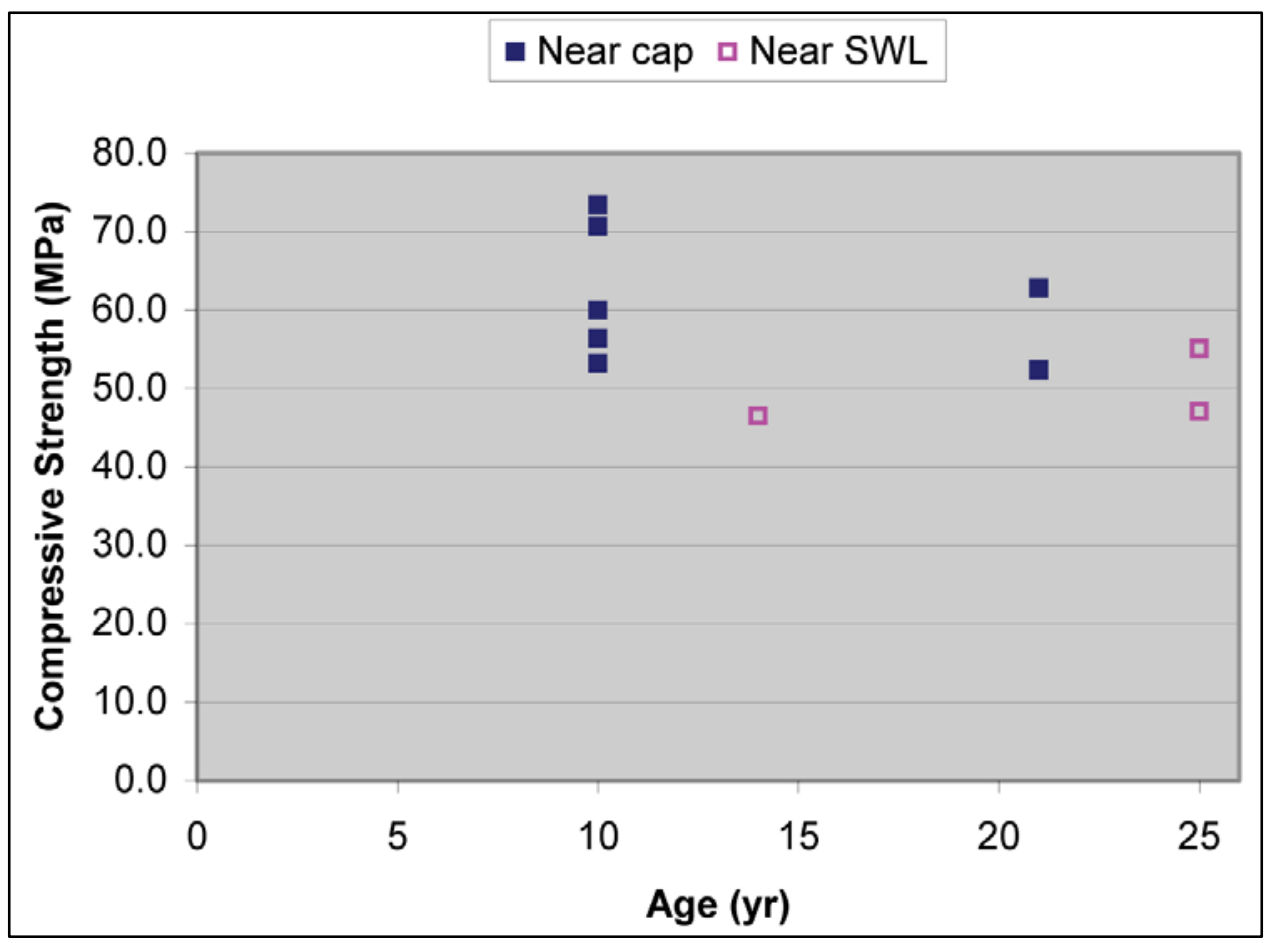

Figure 22. Compressive strength as a function of age

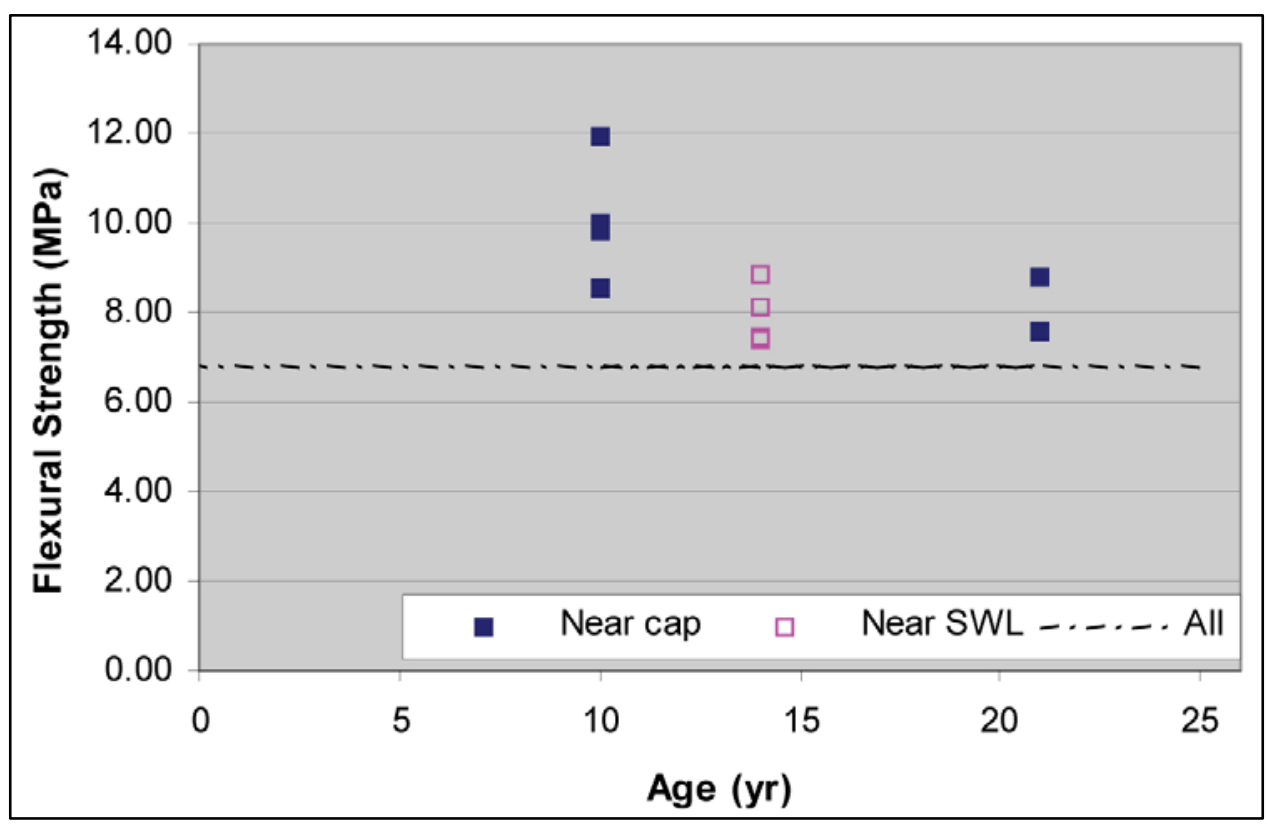

Figure 23. Flexural tensile strength as a function of age 


\begin{tabular}{|c|c|c|c|c|c|c|}
\hline \multicolumn{7}{|c|}{$\begin{array}{l}\text { Table } 3 \\
\text { Concrete Strength Test Results }\end{array}$} \\
\hline Dolos & \begin{tabular}{|l} 
Core \\
Number
\end{tabular} & $\begin{array}{l}\text { Torque Required } \\
\text { to break Cyl with } \\
\text { Tool, N-m }\end{array}$ & $\begin{array}{l}\text { Compressive } \\
\text { Strength } \\
\text { (ASTM C 39) MPa }\end{array}$ & \begin{tabular}{|l} 
Flexural \\
Tensile \\
Strength (tool) \\
MPa
\end{tabular} & $\begin{array}{l}\text { Flexural Tensile } \\
\text { Strength } \\
\text { (ASTM C 293) MPa }\end{array}$ & $\begin{array}{l}\text { Splitting Strength } \\
\text { Tensile } \\
\text { (ASTM C 496) MPa }\end{array}$ \\
\hline \multirow[t]{9}{*}{$559^{b}$} & N1 & - & - & - & 9.79 & 4.31 \\
\hline & N2 & - & 53.24 & - & 8.55 & 2.14 \\
\hline & N3 & - & 56.41 & - & - & 4.59 \\
\hline & $\mathrm{F} 1$ & 136 & - & 6.41 & - & - \\
\hline & F2 & 149 & - & - & - & - \\
\hline & F3 & 149 & - & - & - & - \\
\hline & T1 & - & - & - & - & - \\
\hline & T2 & - & - & - & - & - \\
\hline & T3 & - & - & - & - & - \\
\hline \multirow[t]{7}{*}{$752^{b}$} & N1 & - & 70.69 & - & - & 4.48 \\
\hline & N2a & - & - & - & 11.93 & 3.48 \\
\hline & N2b & - & - & - & - & 3.03 \\
\hline & N3 & \multicolumn{5}{|l|}{ Not tested } \\
\hline & N4 & - & 60.00 & - & 10.03 & 3.48 \\
\hline & \begin{tabular}{|l|} 
N5 \\
\end{tabular} & \multicolumn{5}{|l|}{ Not tested } \\
\hline & N6 & - & 73.45 & - & - & - \\
\hline \multirow[t]{4}{*}{$236^{a, e}$} & N1 & - & 52.34 & - & - & 4.17 \\
\hline & N2 & - & - & - & 8.76 & - \\
\hline & N3 & - & 62.83 & - & 7.55 & 4.14 \\
\hline & $\mathrm{F} 1$ & 122 & - & 7.34 & - & 2.93 \\
\hline \multirow[t]{2}{*}{$330^{c, f}$} & - & - & 47.09 & - & - & - \\
\hline & - & - & 55.11 & - & - & - \\
\hline $598^{\mathrm{d}, \mathrm{g}}$ & - & - & 46.49 & - & - & - \\
\hline \multirow[t]{2}{*}{$298^{d}$} & - & - & - & - & 8.14 & - \\
\hline & - & - & - & - & 7.48 & - \\
\hline \multirow[t]{2}{*}{$380^{d}$} & - & - & - & - & 7.37 & - \\
\hline & - & - & - & - & 8.82 & - \\
\hline \multicolumn{7}{|c|}{ 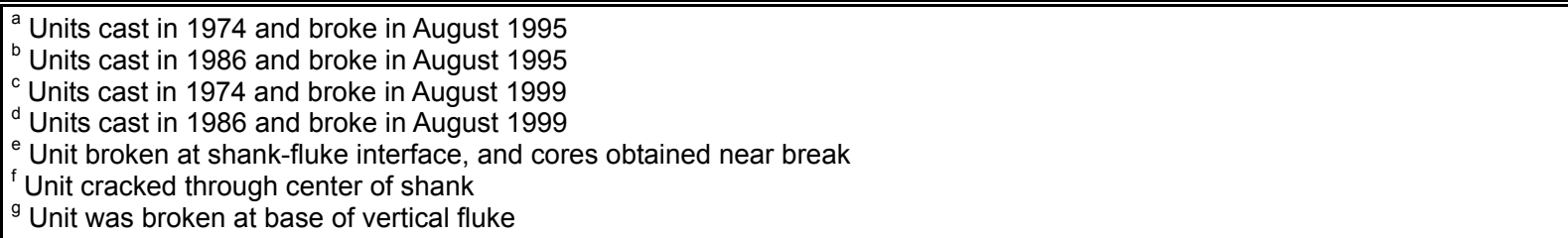 } \\
\hline
\end{tabular}




\section{Conclusions}

This report discusses monitoring of dolosse on the outer Crescent City breakwater. The focus of the monitoring was primarily on dolos movement since the last detailed survey in 1999 and on dolos breakage. Several conclusions can be drawn from the study discussed herein.

a. Dolos movements since originally placed in 1986 and since last measured in 1999 were quantified using photogrammetric measurements. The data previously reported show that significant movement occurred during the first two years after placement. This initial consolidation is referred to as nesting of the structure. The most recent measurements indicate that very little movement has occurred since the nesting period and no significant movement has occurred since 1999.

b. Breakage surveys in 2004 indicated no new breaks since 1993. However, it was noted that more breaks were found using careful walking surveys than discovered by reviews of aerial photographs.

c. The strengths of both the 1974 and the 1986 dolosse have increased substantially since construction. The strength increase was much less near the still water level than near the cap, suggesting strength reduction due to fatigue of the highly loaded units. The average splitting tensile strength was six percent of the compressive strength, and the average flexural strength was 16 percent of the compressive. 


\section{References}

Appleton, W., Kendall, T. R., and Melby, J. A. (1996). "A ten-year history of dolos monitoring at Crescent City." Proceedings of Twenty-Fifth International Conference on Coastal Engineering, ASCE, Reston, VA, 4664-4675.

Baumgartner, R. C., Carver, R. D., and Davidson, D. D. (1985). "Breakwater rehabilitation study, Crescent City Harbor, California; Coastal model investigation," Technical Report CERC-85-8, U.S. Army Engineer Waterways Experiment Station, Vicksburg, MS.

Bottin, R. R., Jr. (1988). "Case histories of Corps breakwater and jetty structures - Report 1 - South Pacific Division," Technical Report REMR-CO-3, U.S. Army Engineer Waterways Experiment Station, Vicksburg, MS.

Bottin, R. R., Jr., and Tolliver, L. R. (1999). "Inspections of previously monitored coastal structures," Technical Report CHL-99-3, U.S. Army Engineer Waterways Experiment Station, Vicksburg, MS.

Bottin, R. R., Jr., Tolliver, L. R., and Myrick, G. B. (2004). "Inspections of previously monitored rubble-mound coastal structures," ERDC/CHL TR-0411, U.S. Army Engineer Research and Development Center, Vicksburg, MS.

Bottin, R. R., Jr., and Meyers D. T. (2002). "Periodic inspections of Kahului and Laupahoehoe breakwaters, Hawaii; Armor unit monitoring for period 1992/93-2001," ERDC/CHL TR-02-11, U.S. Army Engineer Research and Development Center, Vicksburg, MS.

Edminsten, J. R. (1982). "Crescent City Harbor, California - 20 August 1982 in section of outer breakwater dolos section," Memorandum for Record, U.S. Army Engineer Division, South Pacific, San Francisco, CA.

Hales, L. Z., and Richey, D. L. (2004). "Guidance and lessons learned from monitoring completed navigation projects," ERDC/CHL TR-04-10, U.S. Army Engineer Research and Development Center, Vicksburg, MS.

Howell, G. L., ed. (1985). Proceedings of the workshop on measurement and analysis of structural response in concrete armor units. U.S. Army Engineer Waterways Experiment Station, Vicksburg, MS. 
Howell, G. L. (1986). "A system for the measurement of the structural response of dolos armour units in the prototype," The Dock \& Harbour Authority 67 (779), 6-11.

Howell, G. L. (1988). "Measurement of forces on dolos armor units at prototype scale." Proceedings of the International Conference, ASCE, Reston, VA.

Howell, G. L., and Melby, J. A., (1991). "Stochastic estimation of extreme stresses in breakwater concrete armor units," Journal of Hydraulic Research 29(6).

Hudson, R. Y., and Jackson, R. A. (1955). "Design of tetrapod cover layer for rubble-mound breakwater, Crescent City Harbor, Crescent City, California; Hydraulic model investigation," Technical Memorandum 2-413, U.S. Army Engineer Waterways Experiment Station, Vicksburg, MS.

Hudson, R. Y., and Jackson, R. A. (1956). "Stability of Crescent City Harbor breakwater, Crescent City, California," Miscellaneous Paper 2-171, U.S. Army Engineer Waterways Experiment Station, Vicksburg, MS.

Kendall, T. R. (1988). "Analysis of 42-ton dolos motions at Crescent City," Proceedings of the International Conference, ASCE, New York, NY.

Kendall, T. R, Howell, G. L., and Denes, T. A. (1985). "Prototype measurement of the structural response of dolos armor units." Proceedings: West Coast Regional Coastal Design Conference, Oakland, California, Coastal Engineering Research Center, U.S. Army Engineer Waterways Experiment Station, Vicksburg, MS, 288-299.

Kendall, T. R., and Melby, J. A. (1989). "Continued monitoring of 42-ton dolos movements and static stresses at Crescent City." Proceedings of Stresses in Concrete Armor Units, ASCE, Reston, VA, 293-311.

Kendall, T. R., and Melby, J. A. (1992). "Movement and static stress in dolosse: Six years of monitoring at Crescent City." Proceedings of Twenty-Third International Conference on Coastal Engineering, ASCE, Reston, VA, 12851298.

Markle, D. G., and Greer, H. C., III. (1992). "Crescent City instrumented model dolos study: Coastal model investigation," Technical Report CERC-92-15, U.S. Army Engineer Waterways Experiment Station, Vicksburg, MS.

Markle, D. G., Melby, J. A., and Kendall, T. R. (1995). "Periodic inspections of dolosse on Crescent City breakwater, Crescent City, California; Report 1, monitoring data for period 1989-1993," Technical Report CERC-95-5, U.S. Army Engineer Waterways Experiment Station, Vicksburg, MS.

Melby, J. A., and Turk, G. (1995). "Crescent City, California breakwater dolos structural response study," Letter Report to USAE District, San Francisco, U.S. Army Engineer Waterways Experiment Station, Vicksburg, MS. 
Melby, J. A. (2002). "Crescent City, California breakwater dolos structural response study," Letter Report to USAE District, San Francisco, U.S. Army Engineer Research and Development Center, Vicksburg, MS.

Rosati, J., III, and Howell, G. L. (1988). "A hierarchical multiprocessor data acquisition system for field measurement of structural response in breakwater concrete armor units," Proc. 21st Oceans Conf., Marine Technology Society.

Rosati, J., III, and Howell, G. L. (1990). "A field measurement of structural response in breakwater concrete armor units." Proceedings of Stresses in Concrete Armor Units, ASCE, Reston, VA, 149-163.

USAE District, San Francisco. (1992). "Supplement to Comprehensive Condition Survey: Outer breakwater, Crescent City Harbor, Del Norte County, CA," Technical Report, U.S. Army Engineer District, San Francisco, CA. 


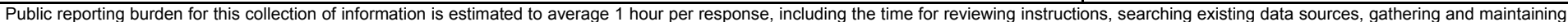

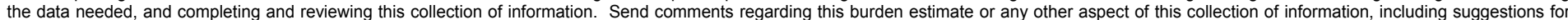

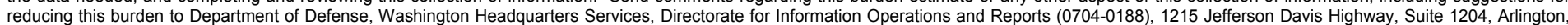

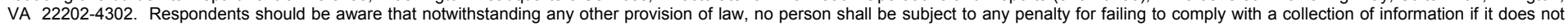
display a currently valid OMB control number. PLEASE DO NOT RETURN YOUR FORM TO THE ABOVE ADDRESS.
1. REPORT DATE (DD-MM-YYYY)
September 2005

4. TITLE AND SUBTITLE

Monitoring of Dolos Armor Units at Crescent City, California
3. DATES COVERED (From - To)

5a. CONTRACT NUMBER

5b. GRANT NUMBER

5c. PROGRAM ELEMENT NUMBER

5d. PROJECT NUMBER

5e. TASK NUMBER

5f. WORK UNIT NUMBER

8. PERFORMING ORGANIZATION REPORT NUMBER

ERDC/CHL TR-05-10

Coastal and Hydraulics Laboratory, U.S. Army Engineer Research and Development Center, 3909 Halls Ferry Road, Vicksburg, MS 39180-6199

Glenn B. Myrick and Jeffrey A. Melby

7. PERFORMING ORGANIZATION NAME(S) AND ADDRESS(ES) (a)

\section{SPONSORING / MONITORING AGENCY NAME(S) AND ADDRESS(ES)}

U.S. Army Corps of Engineers

Washington, DC 20314-1000

10. SPONSOR/MONITOR'S ACRONYM(S)

11. SPONSOR/MONITOR'S REPORT NUMBER(S)

\section{DISTRIBUTION / AVAILABILITY STATEMENT}

Approved for public release; distribution is unlimited.

\section{SUPPLEMENTARY NOTES}

\section{ABSTRACT}

Crescent City breakwater is located on the California coastline approximately 17 miles south of the Oregon border. In 1974 and again in 1986, dolosse were placed along a section of the breakwater particularly susceptible to damage. Monitoring of above water dolosse moment and breakage has been conducted since 1986. In August of 2004, a detailed monitoring survey was conducted of the dolos section of the Crescent City breakwater. The goal of this monitoring is to understand the long-term structural response of the dolosse. Detailed monitoring included ground surveys, aerial photography, photogrammetric analysis, and a broken armor unit survey. Results showed very little dolos movement has occurred since the end of the initial nesting period in 1988. Furthermore, no additional dolos breakage was observed since 1993. From 1995 to 1999, core samples were obtained from dolosse cast in 1986 and in 1974 in order to determine the in-situ strength of units in both non-loaded (near concrete cap) and highly loaded regions (near still water level) of the structure. The cores were subjected to standard laboratory concrete strength tests. Results indicated that the structural strength has increased considerably since construction for non-loaded units. However, concrete strength for units placed in highly loaded units near the still water level was near constant.

\section{SUBJECT TERMS}

See reverse.

16. SECURITY CLASSIFICATION OF:

\begin{tabular}{|l|l|}
\hline a. REPORT & b. ABSTRACT \\
UNCLASSIFIED & UNCLASSIFIED \\
\hline
\end{tabular}

17. LIMITATION OF ABSTRACT

\begin{tabular}{|c|} 
18. NUMBER \\
OF PAGES \\
\cline { 2 - 2 } \\
\cline { 2 - 2 }
\end{tabular}

19a. NAME OF RESPONSIBLE PERSON

19b. TELEPHONE NUMBER (include area code) 
15. SUBJECT TERMS

Aerial photography

Breakwater

Concrete

Crescent City, California

Dolos

Periodic inspections

Photogrammetry

Strength

Surveys 